\section{Análisis estratigráfico de la muralla sur de Contrebia Leukade (Aguilar del Río Alhama, La Rioja)}

José Antonio Hernández Vera*, José Manuel Martínez Torrecilla**, JULIO NúÑEZ MARCÉN** ${ }^{*}$, IBAN SÁNCHEZ PINTO**

* Universidad de Zaragoza

** Grupo de Investigación en Arqueología de la Arquitectura, GIAA, de la UPV/EHU

\section{INTRODUCCIÓN}

Con motivo de la redacción del proyecto de restauración del tramo sur y la puerta sur de la conocida como muralla celtibérica de Contrebia Leukade ${ }^{1}$, se nos encargó la realización de un estudio arqueológico de ambos tramos, fundamentalmente enfocado a determinar su secuencia constructiva para poder acometer una restauración científica de los mismos. En el presente artículo se recogen únicamente los resultados referidos al tramo correspondiente a la muralla.

\section{SITUACIÓN}

Las «ruinas de Inestrillas» están situadas en la margen derecha del río Alhama, afluente del Ebro, en una posición intermedia entre las localidades riojanas de Cervera y Aguilar del río Alhama, perteneciendo al término municipal de esta última.

La antigua ciudad estaba emplazada sobre dos cerros que dejan entre sí una vaguada central que recoge sus aguas para verterlas al río por el norte. El cerro situado al oeste de la vaguada central está formado por un contrafuerte rocoso que, en más de la mitad de su perímetro, se encuentra cortado en vertical sobre el cauce del Alhama, arrojando pendientes superiores al $80 \%$ y, en algunos casos, del 100\%. Estos cortados, además, superan en algunos casos los $60 \mathrm{mts}$. de altura, lo que hace que el acceso por el oeste de la ciudad sea materialmente imposible. El monte que conforma el sector oriental de la ciudad es más elevado que el anterior, pero su transición hacia los valles colindantes se realiza de forma menos brusca descendiendo por el este de forma más suave.

\section{ANTECEDENTES}

Los autores clásicos que se ocupan de narrar la conquista romana de Hispania, y más concretamente de la Celtiberia, son significativamente reiterativas al constatar que una de las características de estas guerras fue que, tras una serie de enfrentamientos realizados en campo abierto en los que los celtíberos llevaron la peor parte ${ }^{2}$, los combates más transcendentes para el desarrollo de las sucesivas campañas bélicas fueron protagonizados por las ciudades indígenas y que

\footnotetext{
${ }^{1}$ Queremos agradecer a D. Óscar Reinares Fernández, arquitecto encargado de dicha redacción, su iniciativa y su constante apoyo durante la ejecución del estudio.

2 Es el caso de la batalla final de la campaña bélica del 188-187 a.C. en la que ejercito romano al mando de L. Manlio infringió una gran derrota a los celtíberos en las proximidades de Calagurris, matando a doce mil de ellos y haciendo prisioneros a otros dos mil (LIVIO, XXXIX, 21). Algunos años más tarde, en el 179 a.C., Tiberio Sempronio Graco volvió a derrotarlos igualmente en una gran batalla de tres días de duración celebrada cerca del Moncayo, en la que se calcula que intervino un ejercito romano compuesto por más de 45.000 efectivos (FATÁs 1975, pp. 300 y ss.) y que, si atendemos de nuevo a las fuentes romanas (Livio, XL, 50), se saldó con un número aún mayor de hispanos muertos.
} 


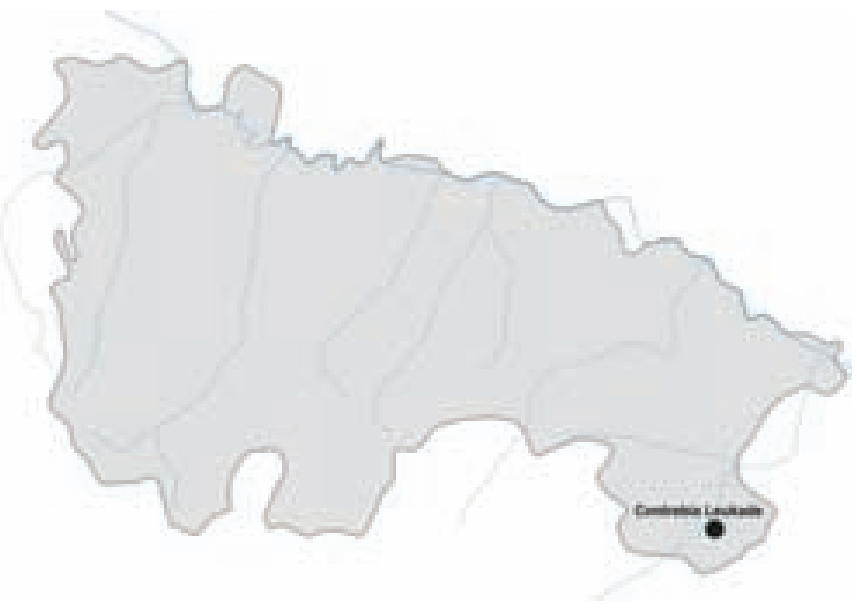

Mapa de situación

las actuaciones más cruentas y castigos más drásticos recayeron, por la misma causa, sobre ellas y sus habitantes.

La tenaz resistencia que ofrecieron muchas de las ciudades citadas en la fuentes al asedio de los ejércitos romanos, táctica y numéricamente muy superiores, obligan a considerar la posibilidad de que realmente estuviesen dotadas de sistemas defensivos eficaces. Sin embargo, nuestro conocimiento al respecto resulta muy parcial, debido a que, en la mayoría de los casos, el estado de destrucción y arrasamiento en que nos han llegado este tipo de obras defensivas hace que en muchas ocasiones resulten irreconocibles los elementos que las integraban y también que, a menudo, incluso delimitar el propio trazado de las mismas sea una labor compleja o imposible de abordar por el momento.

En este contexto, el sistema defensivo de Contrebia Leukade, ciudad con la que se identifican las denominadas historiográficamente «ruinas de Inestrillas», por sus dimensiones, las características de los diferentes elementos que lo integran y el buen estado de conservación de alguna de sus partes, constituye un caso paradigmático de la poliorcética celtibérica y obliga, de nuevo, a suponer que otras ciudades, coetáneas y de similar rango, también protagonistas a la fuerza de las conocidas como "guerras celtibéricas», debieron dotarse de sistemas defensivos semejantes.

Las noticias que proporcionan los diferentes autores clásicos sobre la ciudad y que inciden en la dificultad que entrañaba su conquista, se justifican a la vista de las ruinas y más singularmente de lo que queda en pie de su sistema defensivo. En relación a la campaña del 143-142 a. C., en que fue tomada por Q. Cecilio Metelo, aparece citada como inexpugnable ciudad hispánica (VELEYO, II, 5, 2) y todos los demás autores que se ocupan de este episodio hablan de las dificultades que debió superar el general romano que, sumido en la desconfianza, pudo entrar en la ciudad únicamente tras un ataque por sorpresa que pilló desprevenidos a sus defensores (VALE-
Rio MaXimo, II, 7, 10; Ampelio, L. M., 18; Plutarco I). Años más tarde, en el 77 a.C., Sertorio después de someterla a un largo asedio, pudo tomarla tras abrir una brecha en un punto de la muralla en que se situaba una de las torres defensivas más importantes.

De los elementos que integran el dispositivo de defensa de la Contrebia celtibérica y que pueden observarse en la actualidad destacan el foso y la muralla que cierran el lado este y la mitad oriental del lado sur del perímetro de la ciudad ${ }^{3}$. El primero de ellos, el foso, es el que de inmediato llama más la atención y resulta más impactante. Su presencia es visible desde varios kilómetros de distancia y su conocimiento entre la gente del lugar, que lo denomina "callejón de los moros», se pierde en la noche de los tiempos. Por ello es lógico que haya recibido un tratamiento preferente por cuantos historiadores y eruditos han visitado y descrito las ruinas.

El primero en hacerlo fue Joaquín Traggia que, aprovechando sus frecuentes viajes a Cervera donde su hermano era gobernador, realizó varias visitas a las ruinas. Como buen ilustrado llevó a cabo un profundo reconocimiento de los elementos que se integran en ellas y trato de definir la identidad de la ciudad a la que pertenecían. Respecto al sistema defensivo, que es lo que ahora nos interesa, Traggia lo recorrió y midió dando para el foso abierto en roca viva nueve varas de anchura, diez de profundidad, mayor en la parte de levante y mediodía donde llega a alcanzar catorce varas de anchura, y setecientas de longitud. De la muralla indica que se elevaría a poca altura sobre el foso y que formaría un parapeto simple o una trinchera de poca anchura (TragGia 1792, pp. 157-167).

La información que proporciona pocos años más tarde Llorente carece de interés; más preocupado por definir la identidad étnica de los habitantes de la ciudad y su adscripción dentro del organigrama administrativo del imperio romano, asuntos en los que discrepa respecto a la opinión de Traggia, pasa de soslayo sobre los aspectos materiales de las ruinas (LLORENTE 1807, p. 303).

Tampoco aporta novedades Govantes, pues en el tomo segundo del Diccionario Geográfico Histórico de España, correspondiente a La Rioja, se limita a dejar constancia de su presencia (GOVANTES 1846, pp. 56 y 96).

\footnotetext{
${ }^{3}$ La defensa del lado oeste y de la mitad occidental del lado sur, estaba confiada al pronunciado escarpe, de hasta $60 \mathrm{mts}$. de altura, que corta en vertical la montaña hasta el nivel del río, haciendo innecesario cualquier dispositivo artificial y respecto al lado norte, la parte más baja y vulnerable de la ciudad, los trabajos realizados en la campaña del 2004 han puesto al descubierto la muralla celtibérica de la que, aunque desmantelada en gran parte, cuando se construyó la muralla romana de época imperial, se puede delimitar el trazado y, a partir de los tramos conservados de su alzado, precisar que se trataba de una muralla acodada, circunstancia que luego abordaremos.
} 


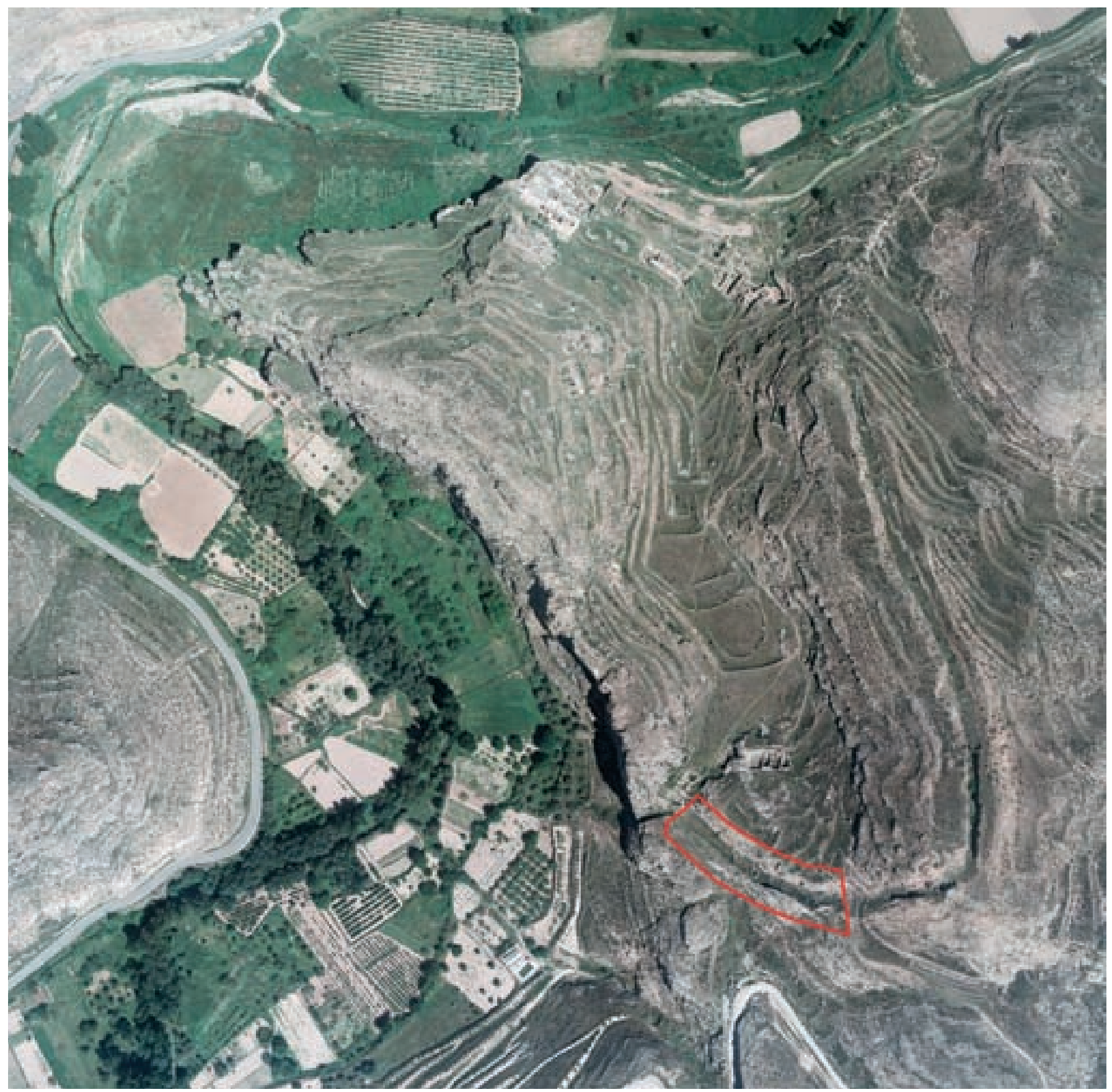

Vista aérea del yacimiento y zona de estudio

Más útil resulta la información contenida en el diccionario dirigido por Pascual Madoz. En relación a las ruinas se indica que, en ese momento, de la muralla que se levanta sobre el foso, se conservaban en pie doscientas varas (MADOZ 1869, voz Inestrillas), refiriéndose, seguramente, al tramo situado en el lado este, coincidiendo con el punto más elevado de la ciudad.

Como es habitual en muchos otros casos no han faltado eruditos locales interesados en las ruinas. En este sentido la obra de Manuel Zapatero, dedicada a Cervera (ZAPA-
TERO 1913), es un claro exponente de los planteamientos y objetivos perseguidos en este tipo de obras en los que la subjetividad y la reivindicación de la importancia del pasado del lugar de origen del autor priman sobre los argumentos y criterios científicos. Sin embargo su atracción por las ruinas y su interés por conocer su identidad y significación histórica le llevaron a contactar con Blas Taracena, a quien comunicó su existencia, logrando que éste investigador, en ese momento director del Museo Numantino, realizara una detenida visita al lugar en 1924. 
Fruto de esta primera visita fue la publicación de un artículo que supuso la incorporación de las ruinas a la historiografía moderna. En él se da cuenta de las características del perímetro del yacimiento arqueológico y de sus elementos más importantes, llegando a la conclusión de que las ruinas debían pertenecer a Contrebia Leukade, la ciudad celtibérica citada por Livio en relación a los acontecimientos que tienen lugar entre el 77 y 76 a.C., durante el desarrollo de la denominada "guerra sertoriana» (TARACENA 1926, pp. 137-142). Esta identificación venía facilitada por los trabajos de Gómez Moreno quien, de acuerdo con las referencias que proporciona el fragmento del libro $91 \mathrm{de}$ Livio, pensaba que la ciudad debía situarse en un punto indeterminado en la frontera de las provincias de La Rioja y Soria.

Respecto a la muralla celtibérica, Taracena proporciona una serie de datos y observaciones que en líneas generales siguió manteniendo en sus publicaciones posteriores y a las que se de forma habitual se han atenido, con posterioridad, cuantos autores se han ocupado de ellas.

Textualmente Blas Taracena comenta los siguientes aspectos del sistema defensivo de la ciudad:

«El reparo que el foso ofrece se duplica con la muralla que, separada no más de $50 \mathrm{~cm}$. de su cara interior, se eleva en toda la longitud de aquel. La muralla, como el foso, se encuentran hoy en bastante buen estado de conservación con una altura media de $4 \mathrm{~m}$. y tan sólo interrumpida por pequeños portillos derruidos. Está formada en sus paramentos por sillarejos de unos 40 a $50 \mathrm{~cm}$. y torpe despiezo, unidos con fuerte mortero, mide $4 \mathrm{~m}$. de grosor, está rellena de mampostería también fuertemente trabada y robustecida cada 6 u $8 \mathrm{~m}$., por unos muros transversales que unen sus paramentos; es de sección rectangular y, por tanto, de paredes verticales. La línea de este recinto forma ángulos obtusos hechos con toda regularidad, es de lienzos rectos y carece de torres y tambores».

Los resultados de las excavaciones realizadas por Taracena más tarde, entre 1934 y 1935, afianzaron su opinión respecto a la atribución de las ruinas a Contrebia Leukade y le permitieron obtener un conocimiento mas preciso de los elementos que se ordenan en su espacio, así como fijar la secuencia ocupacional del lugar (TARACENA 1942, pp. 21-27).

Su intervención en el sistema defensivo celtibérico confirmó, al parecer, sus primeras impresiones respecto a la morfología y la técnica utilizada en la construcción de la muralla, así como el número y disposición de los elementos que se integran en ella. Al respecto, la única novedad vino proporcionada por el descubrimiento de una gran torre de planta cuadrangular de 16 por 12 metros de planta, situada en el punto más elevado de la ciudad, que según el mismo
Taracena indica parece comentario plástico al pasaje de Livio, donde cuenta como el año 77 Sertorio «... levantó otra torre en el mismo lugar... Al mismo tiempo la torre de la ciudad, que era su principal defensa, rotos los fundamentos se derrumbó en grandes hendiduras».

Además de en esta torre, Taracena intervino también en varios tramos de la muralla celtibérica y, entre ellos, en su fachada sur donde excavó en el espacio en que se inician el foso y la muralla, junto al escarpe sobre el río (TARACENA 1942, fig. 9), y en otra zona situada en un punto intermedio, que se corresponde con el extremo inferior del lienzo central de los tres que se conservan en pie en este lado. En este lugar abrió una trinchera en la que documentó un muro transversal al paramento exterior de la misma, afianzando su opinión de que se trataba de uno de los "cajones» que, situados a distancias variables de entre 6 y 8 metros, unirían los dos paramentos externos de la muralla compartimentando sus rellenos internos proporcionando una mayor solidez a la obra.

Por último, en el lado oriental abrió una trinchera transversal al foso y la muralla, que le permitió determinar las dimensiones en profundidad del primero y la morfología de la segunda de la que, al igual que en el resto del perí-

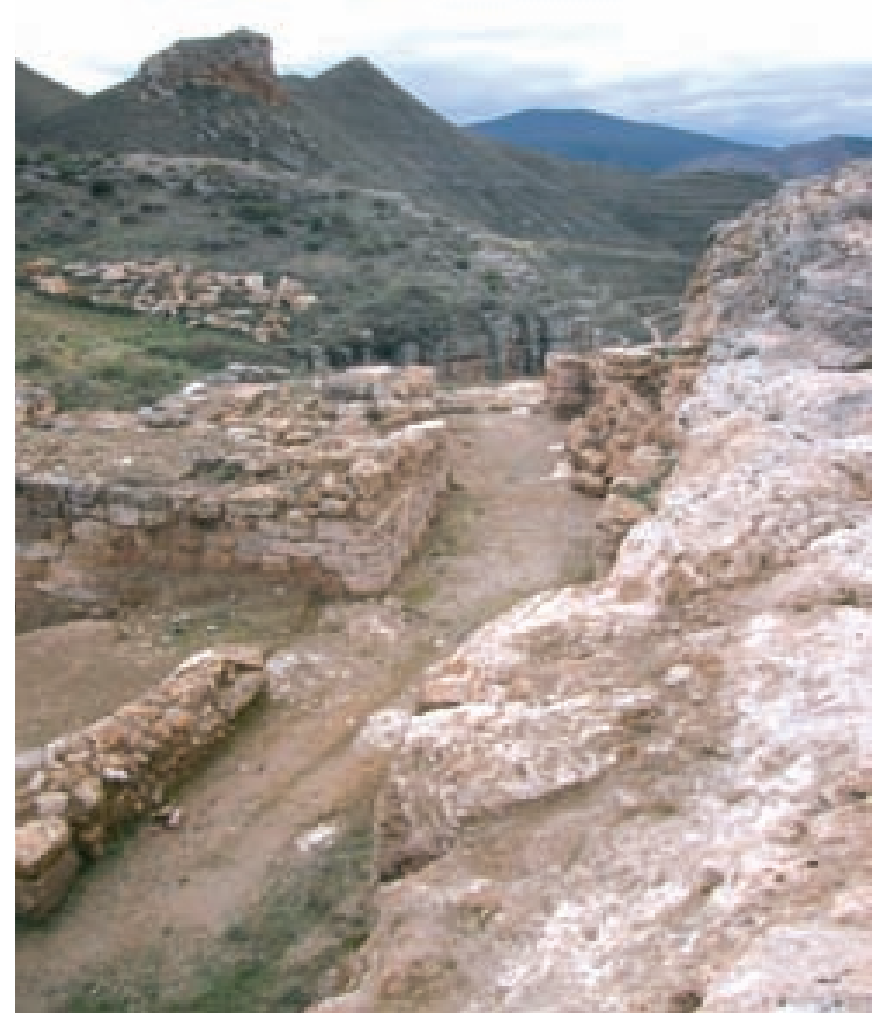

Detalle de la puerta sur 


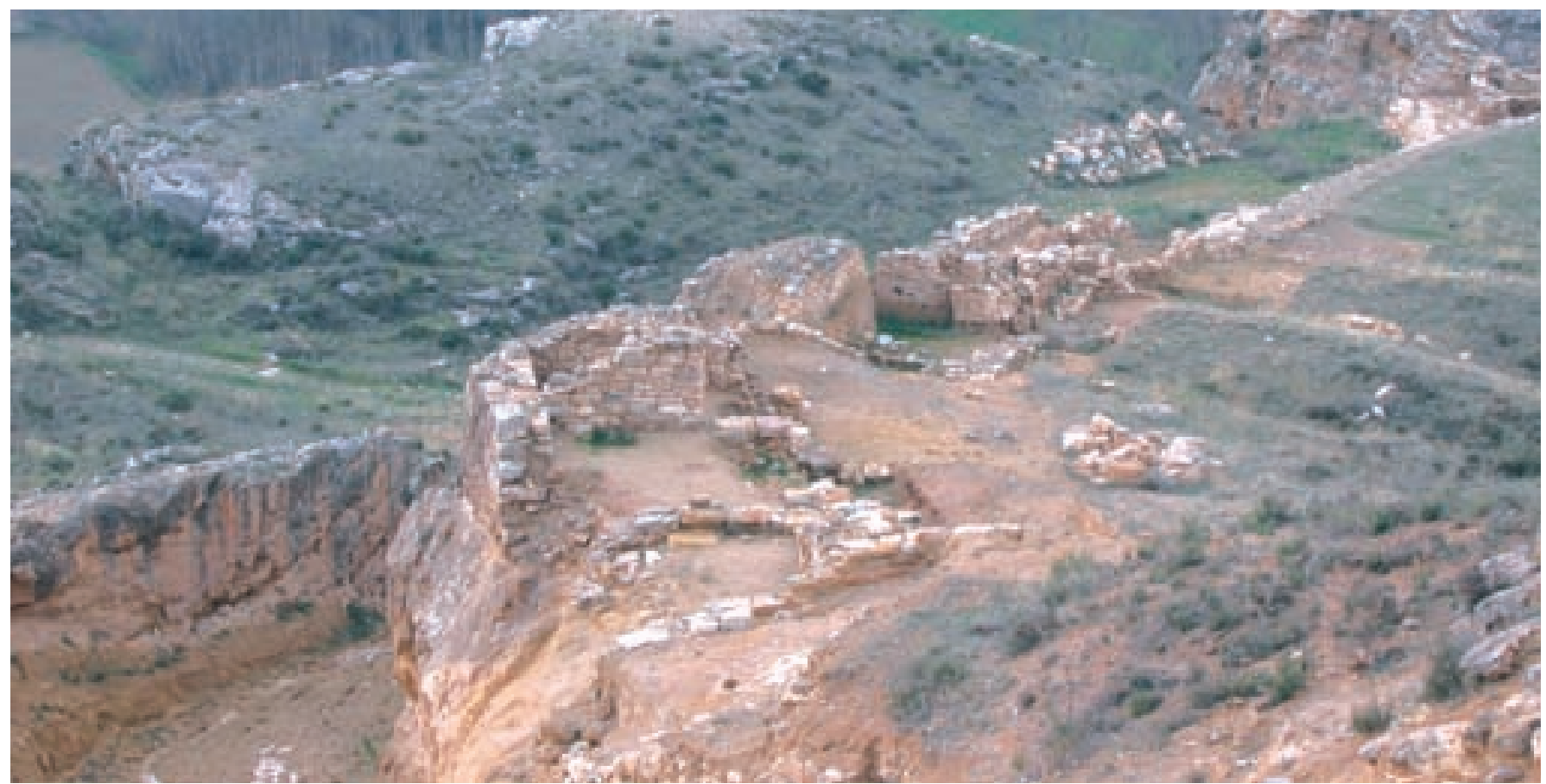

Vista del torreón del sector $C$

metro, creyó que estaba construida a base de dos paramentos (TARACEnA 1942, fig. 7).

El estudio que, años más tarde, realizó uno de los firmantes, se llevó a cabo en base a las publicaciones de Taracena, el estudio de los materiales por él recuperados y que permanecían inéditos y, sobre todo, el detallado análisis de los espacios excavados y de los elementos que, en gran número, permanecen visibles en el mismo yacimiento. Por ello, como era lógico, la mayor parte de las conclusiones no variaban sensiblemente de las expuestas por Taracena (HERNÁNDEZ VERA 1982). Sin embargo, planteaba una serie de observaciones que modificaban sus afirmaciones sobre la morfología de la muralla celtibérica y sobre los elementos que se integran en su fábrica, sobre todo en lo referente a la vertiente meridional de su trazado.

A solucionar las dudas que se nos plantearon entonces han ido encaminadas las intervenciones realizadas en este lado durante las campañas del 2000 al 2003, cuyos resultados parciales se han expuesto recientemente.

\section{EXCAVACIONES RECIENTES}

\section{La puerta y el torreón de la muralla sur}

El análisis de las estructuras descubiertas por Taracena en la parte superior de la vaguada, junto al inicio del foso y la muralla, nos llevó a pensar, hace tiempo, que su interpretación era incompleta y no se ajustaba a los elementos presentes en el lugar y a proponer la existencia en este lugar de una gran torre adosada a la muralla y a la ladera del monte occidental, así como la de una puerta que salvaría el inconveniente del foso mediante un puente, de forma similar a como se hacía en Azaila (HERNÁNDEZ Vera 1982, p. 125).

Las últimas excavaciones han venido a confirmar nuestra propuesta, dejando al descubierto una puerta que en la fase inicial estaba formada por una simple interrupción de la muralla que está engrosada en este punto, y a la que, de forma progresiva, se fueron adosando en su frente exterior una serie de obras que, con el tiempo dieron lugar a un gran bastión que aumentaba considerablemente su capacidad de resistencia. La detenida lectura del alzado de los elementos conservados permite completar los resultados obtenidos en la interpretación del proceso constructivo que recientemente realizamos (HERNÁNDEZ Vera 2003, pp. 61-82).

\section{Espacio intermedio de la muralla sur}

Los muros transversales que, según Taracena, unen sus paramentos hace que la muralla celtibérica de Inestrillas se catalogue, desde el punto de vista tipológico, dentro de las murallas denominadas de "cajones», ajustándose su construcción a un modelo moderno surgido en el Mediterráneo, y que llega a la costa peninsular con las colonizaciones. Esto, unido al desconocimiento de influencias mediterráneas tempranas al interior del Ebro, ha hecho que se le adjudique una cronología avanzada y que se vincule a la presencia de los ejércitos romanos. De acuerdo con esto, Taracena fechó la construcción de la muralla y con ella la 
fundación de la ciudad en un momento posterior a la campaña de Graco, siendo sus habitantes «celtiberos sometidos que continuaron sin apenas variación en sus rústicas costumbres» (TARACENA 1942, p. 27). Por nuestra parte, nos inclinamos por una cronología más temprana, al considerar que, desde la elección del enclave hasta las arquitecturas que se integran en su espacio, no son propios de un pueblo vencido, si no más bien de un pueblo que se presta a hacer frente y detener el avance de un enemigo (HERNÁNDEZ VERA 1982, p. 133). Con todo, la opinión de Taracena ha prevalecido entre quienes recientemente se han ocupado de esta muralla, proponiendo para ella un origen itálico y una datación en época republicana ${ }^{4}$, relacionándola con la segunda fase de la muralla de Tarragona fechada en el tercer cuarto del siglo II a.C. (ASENSIO 1995), apuntándose incluso la posibilidad de que su construcción pudiera retraerse hasta el siglo I a.C. con motivo de las guerras sertorianas (ASENSIO 1996, p. 35).

Sin embargo, el detenido reconocimiento que realizamos hace tiempo, nos llevó a comprobar que en el lado oriental donde se halla el tramo más largo y mejor conservado de la muralla, algunos de los muros transversales se reducían a simples alineaciones superficiales de piedras sin ninguna trabazón con los paramentos. En el lado sur, por su parte, otros muros que parecían ajustarse mejor a las descripciones de Taracena, rebasaban ampliamente el paramento interno de la muralla. Esto era particularmente evidente en la trinchera abierta por Taracena y nos llevó a pensar en que, más bien, debía corresponder a una torre de planta rectangular que, condicionada por la presencia del foso, se proyectaba hacia el interior, al igual que la gran torre rectangular levantada en el punto más elevado de la ciudad, y que, probablemente, debían existir otras de características similares (HERNÁNDEZ VERA 1982, p. 126).

Por otra parte, la simple observación de los tres tramos conservados en pie pone de manifiesto marcadas diferencias en lo que a los materiales y su disposición se refiere, que están indicando la existencia de diferentes momentos constructivos debidos a reparaciones de emergencia durante los años en que la muralla estuvo operativa.

La excavación en este punto durante las campañas del 2000 y 2001 tenía como objetivo determinar la naturaleza de los muros transversales y su funcionalidad dentro del

${ }^{4}$ Asensio Esteban, J.A. (1996): Influencia de la poliorcética tardo-republicana en los sistemas defensivos de las ciudades indígenas del valle medio del Ebro: El caso de las murallas denominadas de cajones, Anas, 9: p. 26; Romeo Marugán, F. (2002): Las fortificaciones ibéricas del valle medio del Ebro y el problema de los influjos mediterráneos, en P. Moret y F. Quesada (eds.) La guerra en el mundo ibérico y celtibérico (ss. VI-II a. de C.), Collection de la Casa de Velásquez (78), Madrid, pp. 167-168. sistema defensivo y determinar la intensidad y cronología de las reparaciones.

Para ello se abrió una superficie de $600 \mathrm{~m} 2$ distribuidos en una banda de 50 por $12 \mathrm{~m}$. que afectaba tanto al exterior como al interior de la muralla.

Los resultados más positivos se obtuvieron en el interior y vinieron a demostrar la no existencia de la supuesta muralla de «cajones», ya que los muros transversales corresponden, como habíamos supuesto, a torres rectangulares destacadas al interior, pudiéndose conocer que inicialmente la muralla constaba de un muro de un metro de grosor, a cuya cara interna se adosaban torres de planta rectangular compartimentadas interiormente en dos espacios.

Un sondeo realizado en uno de los tramos conservados en el lado oriental vino a indicar que también aquí se siguió el mismo criterio.

Como consecuencia de las guerras y asedios la configuración de la muralla fue alterándose, resultando visibles las reparaciones y correcciones realizadas en ella.

\section{METODOLOGÍA}

Formando parte del proyecto de restauración parcial de la muralla de Contrebia Leukade, se ha llevado a cabo una lectura estratigráfica de los aquellos elementos sobre los que se iba a intervenir. Esta investigación parcial, dentro de un sistema defensivo más amplio, se integra en el proyecto de investigación arqueológica integral del yacimiento.

Esta intervención es la primera aplicación de la metodología específica de la Arqueología de la Arquitectura sobre la muralla de Contrebia Leukade, por lo que, además de aportar los datos arqueológicos necesarios para llevar a cabo una restauración científica de la muralla, los resultados se integrarán en el contexto general de la investigación, sirviendo, además, para dotarnos de la experiencia e instrumentos necesarios para llevar a cabo, en el futuro, un estudio completo del sistema defensivo de la ciudad.

Antes de comenzar a describir la metodología que hemos empleado, creemos necesario describir los condicionantes principales a que se ha visto sujeto el estudio y que son, en definitiva, los que han llevado a definir el procedimiento de trabajo.

La zona sobre el que actuamos, pese a ser una de las que presenta un mejor estado de conservación dentro de muralla, se encuentra formada por varios tramos sin conexión física y, por otra parte, al no haberse realizado una limpieza completa de su parte superior, se mantienen una serie de depósitos que ocultan la conexión visual entre la cara interna y la externa.

Esto suponía que la mayor dificultad no se iba a plantear en la lectura estratigráfica de los tramos, que no pre- 
sentaban una excesiva complejidad, sino en el momento de realizar la síntesis final.

Hay que señalar en este caso que se optó por pasar directamente de una primera lectura analítica, formada por unidades estratigráficas, a una síntesis final en fases constructivas, sin el paso intermedio de articular la secuencia en actividades y grupos de actividades. Esta decisión se fundamentó en la propia configuración del tramo de muralla estudiado, en el que las relaciones físicas de las unidades estratigráficas eran escasas, por lo que las actividades y grupos de actividades, en la mayoría de los casos, se hubiesen limitado únicamente a la integración de las unidades constructivas con las superficies realizadas para su asiento.

La lectura comenzó con la identificación de cada una de las unidades estratigráficas, que fueron registradas tanto alfanuméricamente, por medio de fichas, como gráficamente, mediante su delimitación en la cartografía digital generada mediante técnicas fotogramétricas y la realización de fotografías digitales. Estas fotografías, en el caso del paramento interno, sirvieron de base para la representación gráfica de las unidades estratigráficas, ya que no se disponía de una cartografía detallada de esta zona.

Al establecer la secuencia estratigráfica con las unidades registradas, se puso de manifiesto la imposibilidad de articular un diagrama general periodizado debido a la falta de continuidad física entre diferentes partes del tramo estudiado. Por ello, para la definición de las fases constructivas ha sido necesario manejar criterios estratigráficos $y$, también, de carácter tipológico.

Se registraron una serie de variables constructivas presentes en cada una de las unidades estratigráficas, referidas al tipo de piedra utilizada, aparejos y combinaciones de aparejos, medidas de los elementos, tratamiento de las superficies, utilización y tipos de morteros ${ }^{5}$.

La presencia de combinaciones similares de variables constructivas en diferentes unidades estratigráficas sin continuidad física, nos permitió asignarlas a una misma fase.

Este proceso, además, nos proporcionó la caracterización constructiva de cada una de las fases, que quedó registrada en un conjunto de fichas como instrumento para el estudio del resto de la muralla, donde la desconexión física de los tramos conservados es todavía más acentuada que en la parte estudiada.

\footnotetext{
5 Aunque modificado por los condicionantes propios del objeto de nuestro estudio y de la limitaciones de calendario y parcialidad de la intervención, la definición de la metodología utilizada para esta parte de la intervención es en gran medida deudora de lo expuesto por A. AZKARATE en "Intereses cognoscitivos y praxis social en Arqueología de la Arquitectura", Arqueología de la Arquitectura, 1, Vitoria 2002, pp. 65-70.
}

Este método de definición de fases en función de la similitud de variables constructivas fue corregido en algunos casos, como en la definición de la fase 3, donde, a pesar de no poseían las mismas variables, su secuencia estratigráfica nos hizo agruparlas o en el caso de los torreones internos de la fase 2 , en el que además de la coincidencia de las variables constructivas se tuvieron en cuenta criterios de similitud estructural y funcional.

\section{CARACTERIZACIÓN CONSTRUCTIVA DE LAS FASES DE LA MURALLA SUR DE CONTREBIA LEUKADE}

\section{Fase 1}

Se trata de una fase documentada en todos los sectores contemplados en el análisis estratigráfico pero, lógicamente, conservada sólo de forma muy parcial en todos ellos. Únicamente puede hablarse de una zona en la que sus diferentes elementos aparecen lo suficientemente conservados como para poder abordar una caracterización correcta de su alzado completo, zona que se corresponde con la posición del que denominamos torreón del sector $\mathrm{C}$, si bien es preciso anotar que algunas de sus características morfológicas pueden identificarse claramente en el resto de las unidades atribuidas a este momento inicial de las defensas del flanco meridional de la ciudad.

A nivel de sistema constructivo la solución que denominamos fase 1 se reconoce, en primer lugar, por partir de una preparación relativamente cuidada de la roca natural, en la que es posible reconocer incluso camas de asiento realizadas exclusivamente para recibir una pieza concreta, ya que una de las preocupaciones recurrentes de los constructores de esta primera fase parece haber sido la de solventar la pronunciada pendiente del cerro en el que se apoya, creando planos constructivos escalonados delimitados y sostenidos por sillares de gran volumen y altura, que podríamos calificar de auténticos orthostatos, encargados de proporcionar un punto de apoyo suficiente a las diferentes hiladas del zócalo que permiten solventar las diferencias de cota.

Desgraciadamente, estas importantes piezas en el sistema estructural del lienzo original han sido, como es lógico por otra parte, objeto de especial reaprovechamiento a lo largo del tiempo y buena parte de la ruina de esta zona del sistema defensivo de la ciudad podría atribuirse, sin duda, a su expolio.

Otra de las características definitorias de este primer momento constructivo es la de su perfecta adecuación al trazado y morfología del gran foso que delimita el sistema defensivo de la ciudad en esta zona, adecuación que evidencia claramente una concepción y realización unitaria de ambos elementos, aunque necesariamente las diferentes re- 


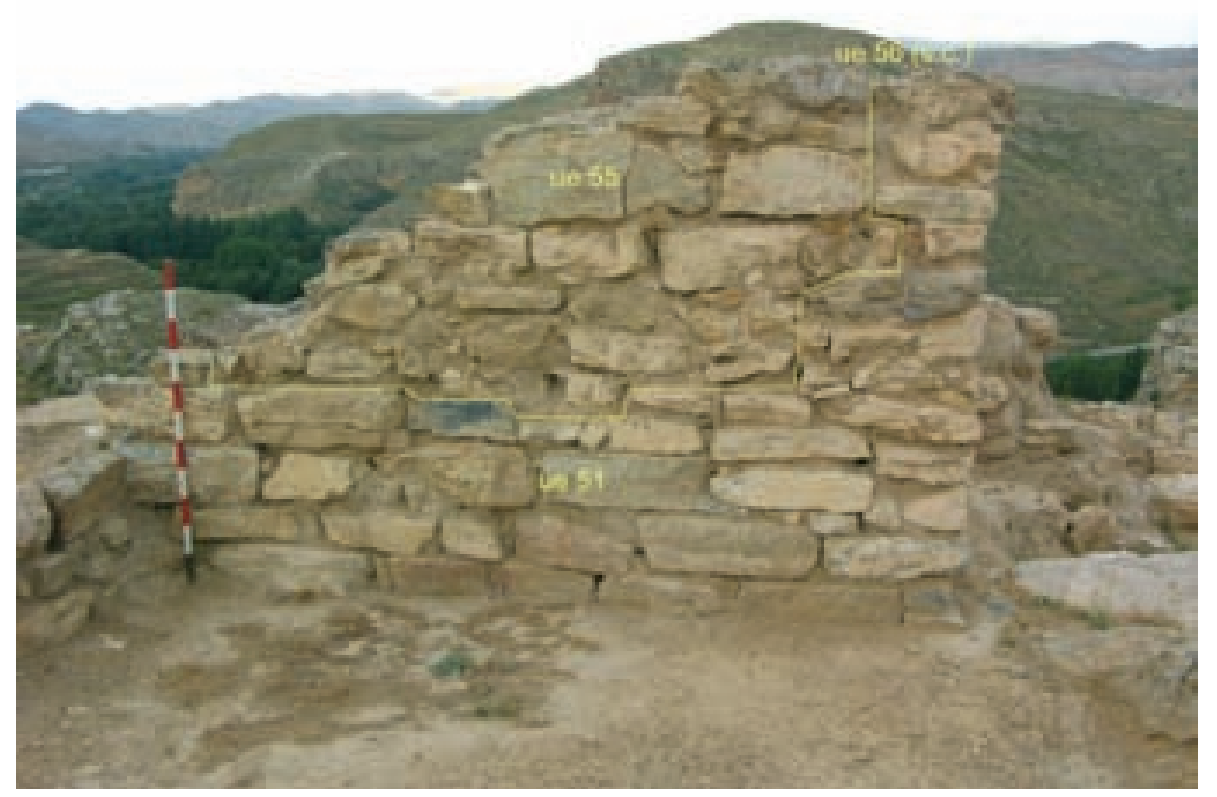

formas realizadas a lo largo del tiempo afectan más o menos acusadamente a esta relación.

Gracias a la conservación en altura del torreón del sector $\mathrm{C}$, puede apuntarse también que el alzado de esta primera fase no fue completamente vertical y que presenta una ligerísima inclinación hacia el interior de la ciudad, fácilmente reconocible en la fotogrametría.

En altura, la primera fase constructiva que reconocemos muestra tres tipos de aparejo perfectamente diferenciados, tanto por su función como por la morfología y naturaleza de las piezas que los componen. Tal diferenciación no obedece, sin embargo, a momentos de construcción diferentes, como podría parecer, sino que los tres tipos de aparejo conforman un sistema perfectamente estructurado para adecuarse a la difícil orografía del terreno y, a la vez, constituir una defensa eficiente no exenta, en cualquier caso, de otro tipo de preocupaciones ya fueran técnicas, poliorcéticas o simplemente estéticas, que resultan imposibles de evaluar por el momento.

La parte inferior, que denominaremos zócalo, es la encargada de proporcionar los planos constructivos escalonados que permitieron levantar la muralla sobre la escarpada ladera. Las piezas más importantes de su estructura son, como avanzábamos, una serie de grandes bloques en los que destaca la altura y que sirven de punto de apoyo inicial a las diferentes hiladas que componen el zócalo, por lo que su colocación precedería a la construcción de los mencionados planos. Son únicamente dos bloques de este tipo los que nos han llegado, siendo los dos coincidentes con la posición de las esquinas del torreón del sector B. Se trata en ambos casos de grandes bloques bien trabajados y escuadrados, con un acabado más cuidado que el resto de las piezas que forman parte del zócalo. En altura alcanzan un desarrollo equivalente a dos o más hiladas del zócalo y, aunque en la actualidad solo conservamos bloques únicos, parece evidente que debían multiplicarse en altura para salvar eficientemente las fuertes diferencias de cota que plantea la ladera. De igual forma, parecen haberse duplicado en anchura, al menos en la cota más baja, como atestigua el bloque más occidental de los conservados que se adosaba a un gran bloque lateral, bloque hoy desaparecido pero del que tenemos constancia por la huella dejada durante su ajuste a la roca natural.

Las hiladas internas que completan el zócalo se ordenan también en función de la pendiente, arrancando desde piezas muy irregulares que van adaptándose a la ladera para ir poco a poco ganando en regularidad. Esta misma adaptación hace que en las zonas más orientales de los diferentes planos constructivos aparezcan bloques más altos, cuya misión es simplemente la de acomodar la horizontal de dos hiladas consecutivas con el plano inclinado de la ladera. Se trata, indudablemente, de piezas muy operativas desde el punto de vista constructivo, pero que alteran visualmente la isodomía de las hiladas y nos ofrecen una visión deformada de la realidad constructiva original. Los bloques que conforman estas hiladas internas del zócalo nos presentan una morfología más variada, que va desde las pequeñas lajas, que predominan en las zonas más bajas para adaptarse mejor a la pendiente, hasta bloques de buen tamaño cua- 
drangulares, trapezoidales e incluso alguna pieza que podríamos calificar de poligonal, morfologías que se combinan con la condición de soga o tizón sin alternancias regulares en lo observado. En cuanto a la talla de estos bloques no es, aparentemente, tan cuidada como la que describíamos para los orthostatos, pero esto no quiere decir que se trate de una factura irregularmente intencionada. En nuestra opinión, y desde la observación detallada de las diferentes zonas conservadas del paramento, buena parte de la aparente deficiencia de su talla debe achacarse a los efectos de la profunda erosión que el paso del tiempo ha producido en aristas y juntas, puesto que a nivel interno los bloques encajan de forma mucho más ajustada de lo que la cara exterior nos muestra en la actualidad.

El segundo tipo de aparejo atribuido a la primera fase, y que denominamos hiladas de regularización, tiene la función específica de complementar la búsqueda de la horizontalidad proporcionada por el zócalo, eliminando las deficiencias de los bloques del paramento inferior y a la vez proporcionar asiento horizontal, ya casi perfecto, al paramento superior. A nivel de conservación, únicamente podemos observar esta parte del paramento original en dos zonas, correspondientes a un pequeño fragmento de paño original (UE 138) y al situado en el torreón del sector C, desde los que puede definirse como dos hiladas de lajas, o mejor de bloques tabulares si consideramos su altura y lon- gitud. Como es lógico, la hilada inferior es la que asume las irregularidades del paramento inferior, lo que se traduce en mayores diferencias de tamaño y asiento de sus piezas, mientras que la superior nos ofrece piezas más homogéneas en altura.

Sobre estas dos hiladas de regularización se asienta el tercero de los tipos de paramento que componía los lienzos de la primera muralla, paramento que constituiría el alzado propiamente dicho de la misma. Su conservación se reduce al fragmento de muralla primitiva situado a la altura del torreón del sector $\mathrm{C}$, donde por fortuna pueden observarse hasta dos hiladas del mismo. Dichas hiladas están compuestas por bloques rectangulares de gran longitud y ajuste perfecto, características que permiten hablar de un auténtico opus quadratum de muy buena calidad con hiladas perfectamente horizontales y de altura constante, aunque está última dimensión difiera entre las dos hiladas conservadas.

La concepción tripartita del alzado de la muralla original no se refleja, sin embargo, únicamente en la técnica constructiva, sino que también los materiales empleados muestran una selección específica para cada una de las comentadas partes del lienzo. Así, en el zócalo el material elegido es el que denominamos caliza de tipo $\mathrm{A}$, mientras que en las dos hiladas de regularización se combinan piezas de caliza $\mathrm{A}$, con otras de tipo $\mathrm{B}$ e, incluso, una de roca pizarrosa. Por su parte, para el

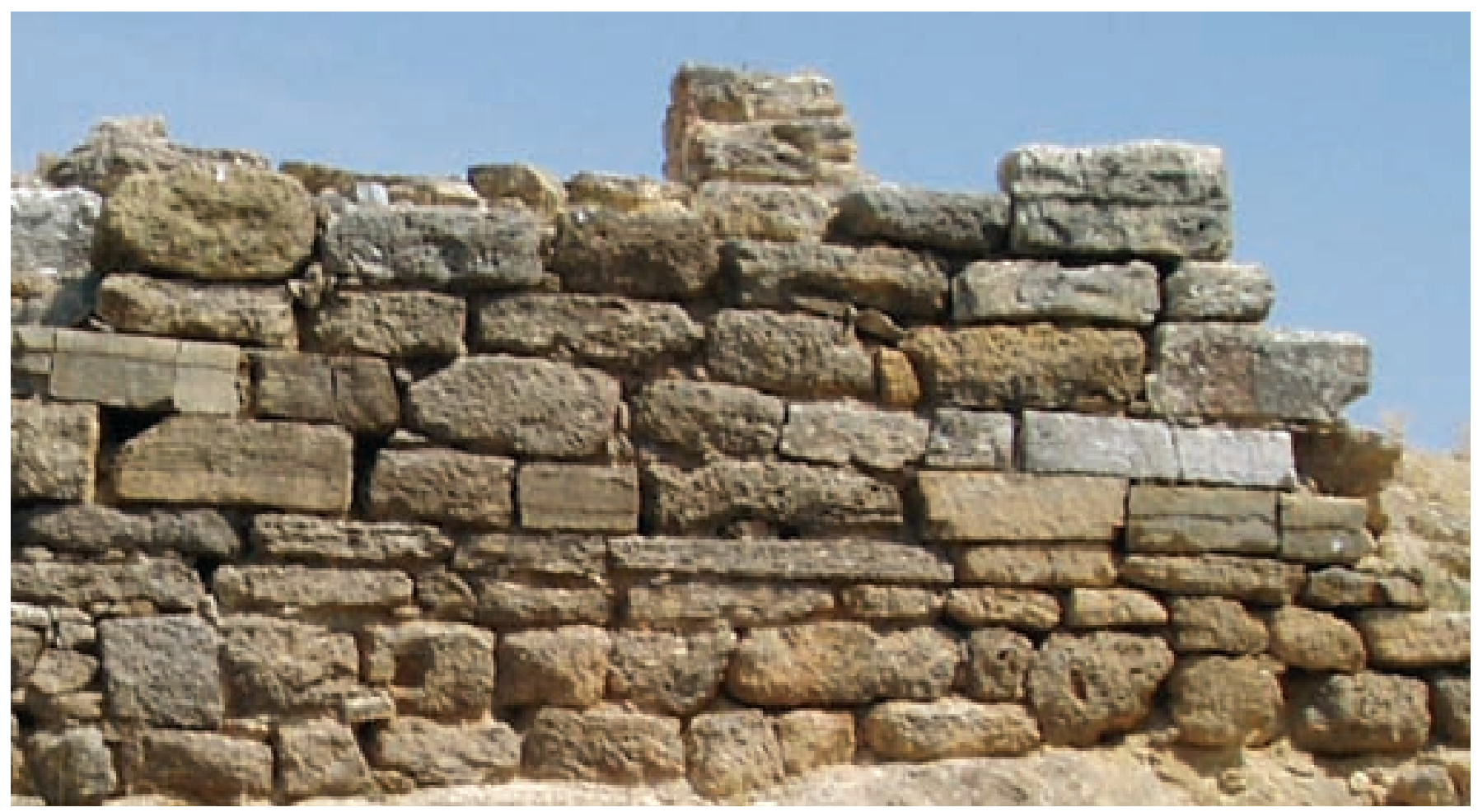

Detalle del alzado exterior del torreón del sector C 


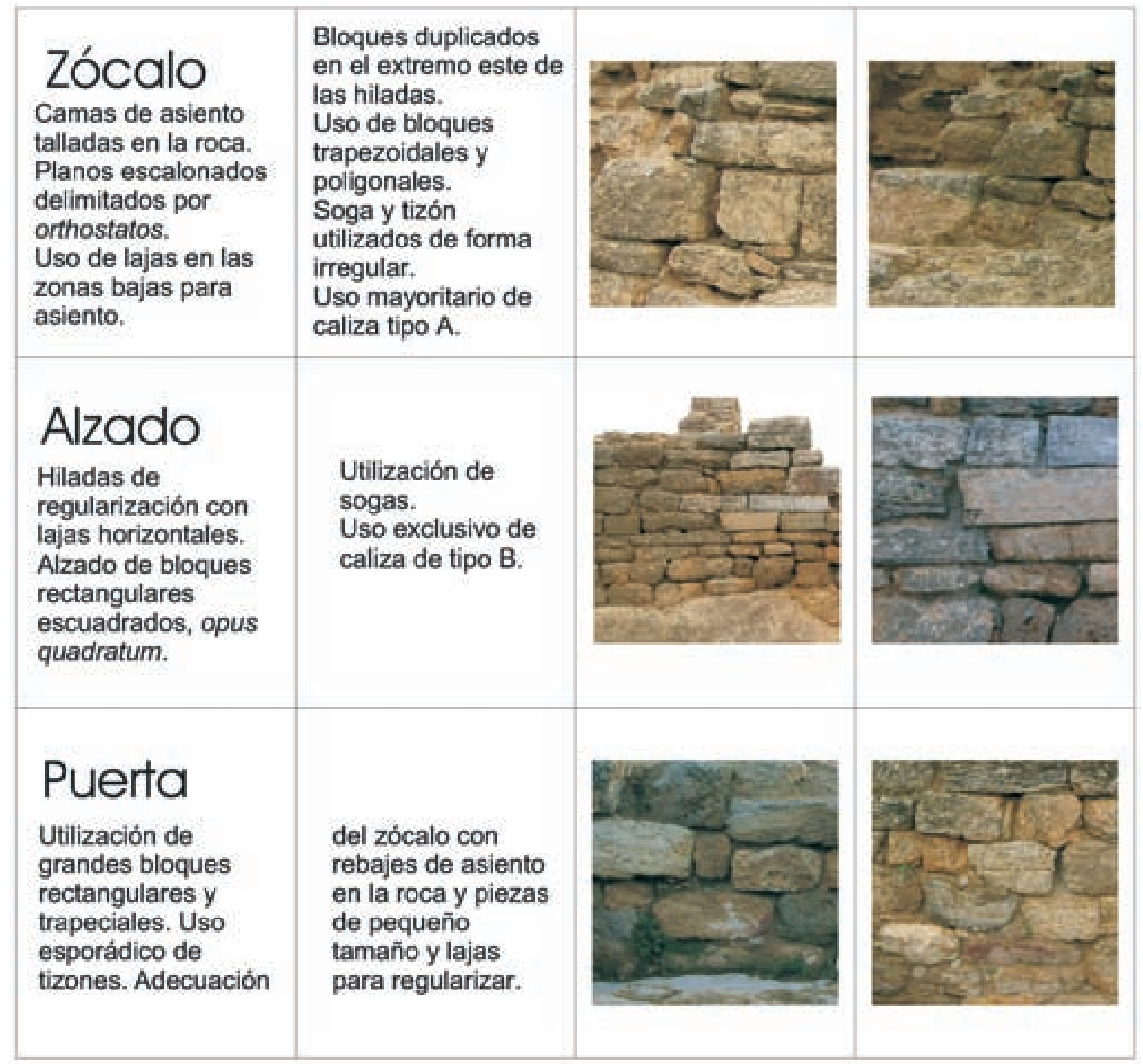

Caracterización constructiva de la Fase 1

opus quadratum del alzado, al menos en lo conservado, se utilizó exclusivamente la caliza que denominamos de tipo B.

\section{Fase 2}

Incluimos en esta segunda fase los paramentos que dan forma a la planta original de los torreones conservados en los sectores $\mathrm{B}$ y C, en los que se distinguen dos formas de construir perfectamente diferenciadas. Por un lado el lienzo exterior, únicamente conservado en el torreón del sector C, y por otro los muros correspondientes al perímetro de los torreones así como al muro divisorio interno. Ambas obras, sin embargo, traban entre sí correctamente, por lo que las diferencias existentes entre una y otra obra deben achacarse, obviamente, a la diferente función de las mismas.

El paramento correspondiente a la fachada externa del torreón se apoya directamente sobre los sillares de opus quadratum correspondientes a la primera fase de la muralla y se encuentra construido mediante bloques de tamaño medio y grande de caliza de tipo A.

En cuanto a la morfología de estos bloques, aunque predominan las piezas de tendencia rectangular, pueden observarse también bastantes bloques de formas trapeciales 
Detalle de una pieza de ángulo entre el muro divisor del torreón $\mathrm{C}$ y el paramento interno de la muralla de la Fase 2

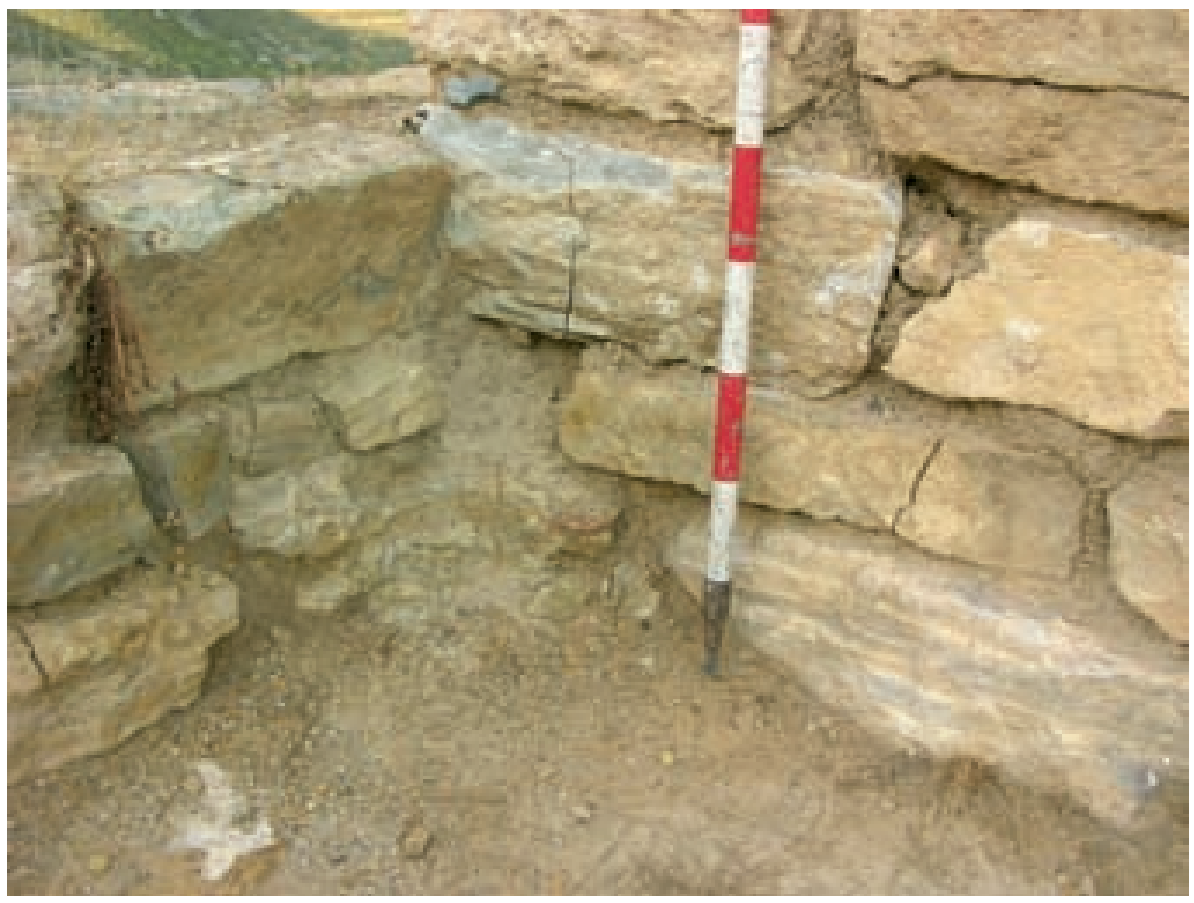

con sus caras laterales oblicuas, característica que nos indica un cierto trabajo de talla a la hora de ajustar las diferentes piezas. A pesar de ello los bloques presentan dimensiones muy variables entre sí y en especial en lo que a altura de los mismos se refiere, dimensión que puede variar incluso dentro de un mismo bloque. Las hiladas presentan por tanto un perfil muy sinuoso y un aspecto irregular, acentuado actualmente por la grave erosión sufrida por la mayoría de las piezas que conforman este lienzo. Esta misma irregularidad hizo necesaria la utilización de pequeños ripios que solventasen la diferencia de altura en los diferentes bloques, elementos que son especialmente visibles y significativos en las líneas de contacto con el paramento de la fase anterior.

En lo que respecta a los lienzos correspondientes al torreón interior cabe distinguir dos zonas diferenciadas en altura: la cimentación y el alzado. En la cimentación predominan los grandes bloques tabulares, de escasa altura pero gran longitud, bloques en los que, a nivel general, se utilizó preferentemente caliza del tipo B, pero también las calizas de tipo A, las rocas de tipo pizarroso y la cuarcita, estas dos últimas documentadas en el torreón del sector B. A nivel técnico, la cimentación dispone sus bloques en sogas y tizones, que en ocasiones llegan a superar la anchura del propio cimiento, pero la ordenación de ambos elementos no responde a alternancias regulares en lo conservado.

Respecto a la talla, los bloques presentan el trabajo imprescindible para su extracción, pero el material pre-

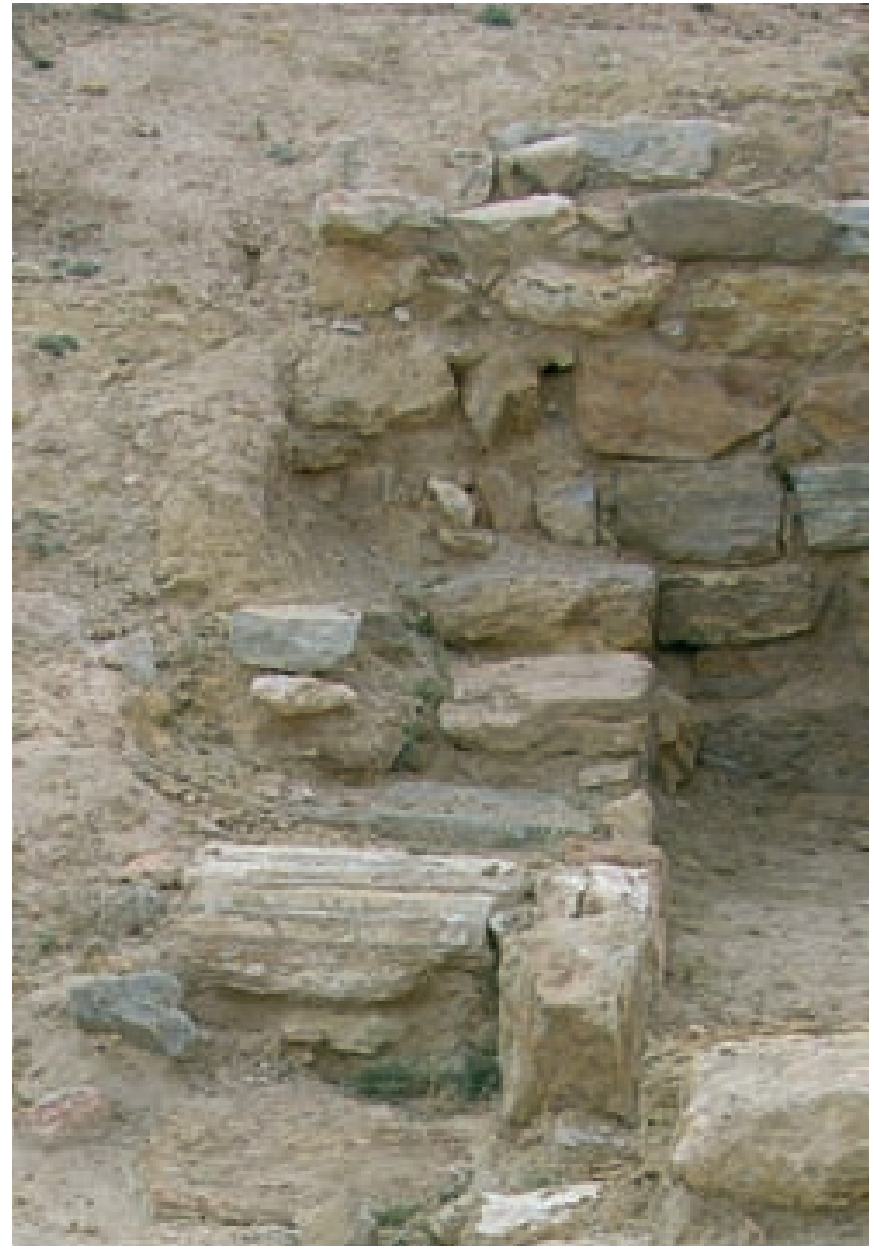

Detalle del aparejo con lajas verticales en el muro norte del torreón C 


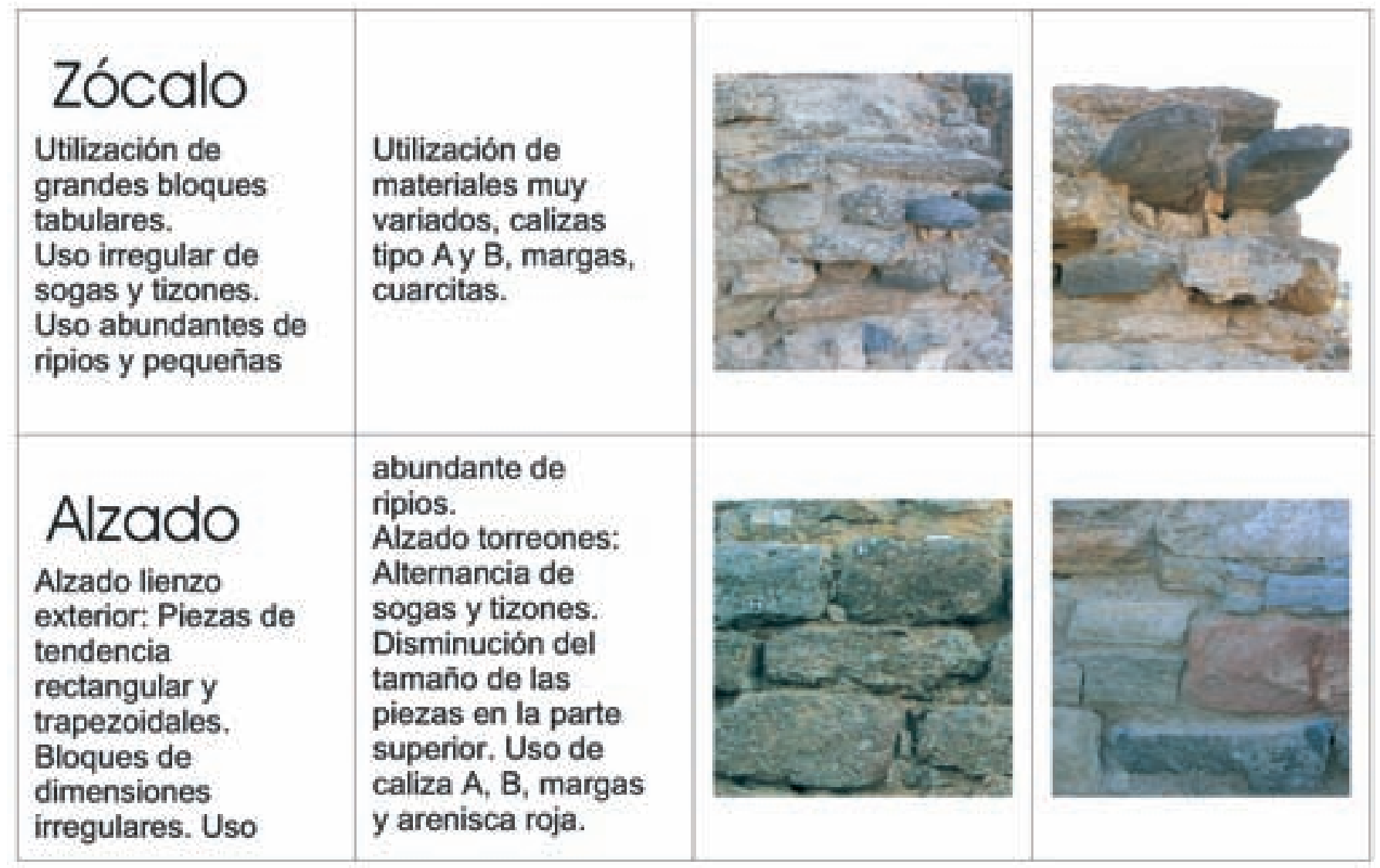

Caracterización constructiva de la Fase 2

ferentemente empleado parece fragmentarse naturalmente en capas, más o menos, horizontales, lo que favorece su apariencia regular. En cualquier caso, la ausencia de talla de ajuste es evidente y por ello son frecuentes los ripios y pequeñas lajas de asiento entre los bloques.

El alzado de los torreones muestra una utilización de materiales similar a la descrita para su cimentación, con la única excepción del torreón del sector $\mathrm{C}$ donde, además de los tipos de material reseñados, se documentan tres únicas piezas elaboradas en una arenisca rojiza ausente en el resto de los tramos del sistema defensivo analizados. Desde el punto de vista de la técnica y la talla, al alzado interno de los torreones es también muy similar a lo descrito para su cimentación, siendo únicamente reseñable que en altura los paramentos tienden a utilizar bloques más pequeños, reservando para las hiladas iniciales las piezas de mayor tamaño.

No obstante, es necesario reseñar la curiosa disposición de los bloques en un pequeño tramo correspondiente a las tres primeras hiladas de alzado del muro septentrional del torreón del sector $\mathrm{C}$, concretamente en las proximidades de la esquina nororiental del bastión. En ese punto, la habitual disposición aleatoria de sogas y tizones, fue sustituida por una articulación del muro en la que se combinan piezas de una anchura ligeramente inferior a la sección del paramento complementadas con lajas verticales de igual altura. Piezas estas últimas que se alternan de interior a exterior en las tres hiladas conservadas. Esta peculiar técnica traba perfectamente con la obra descrita anteriormente, por lo que parece bastante razonable atribuir esta peculiar técnica a la intervención, durante la construcción de los torreones, de maestros canteros diferentes.

\section{Fase 3}

El aislamiento físico que produce la deficiente conservación de la muralla entre las unidades constructivas reconocibles, nos obliga a incluir, por diferentes razones estratigráficas, tres tramos dentro de la tercera fase: uno en el sector A, coincidente con la zona mejor conservada del mismo, un recrecido del muro externo del torreón del sector $\mathrm{B}$ y, por último, el tramo relacionado con la importante reforma que modificó por completo la planta del torreón del sector C. No obstante, resulta poco probable que estas tres importantes reformas fuesen realizadas de forma simultánea, habida cuenta de las diferencias técnicas y formales existentes entre ellas.

El tramo correspondiente al sector A se caracteriza, en primer lugar, por presentar un marcado perfil inclinado en 


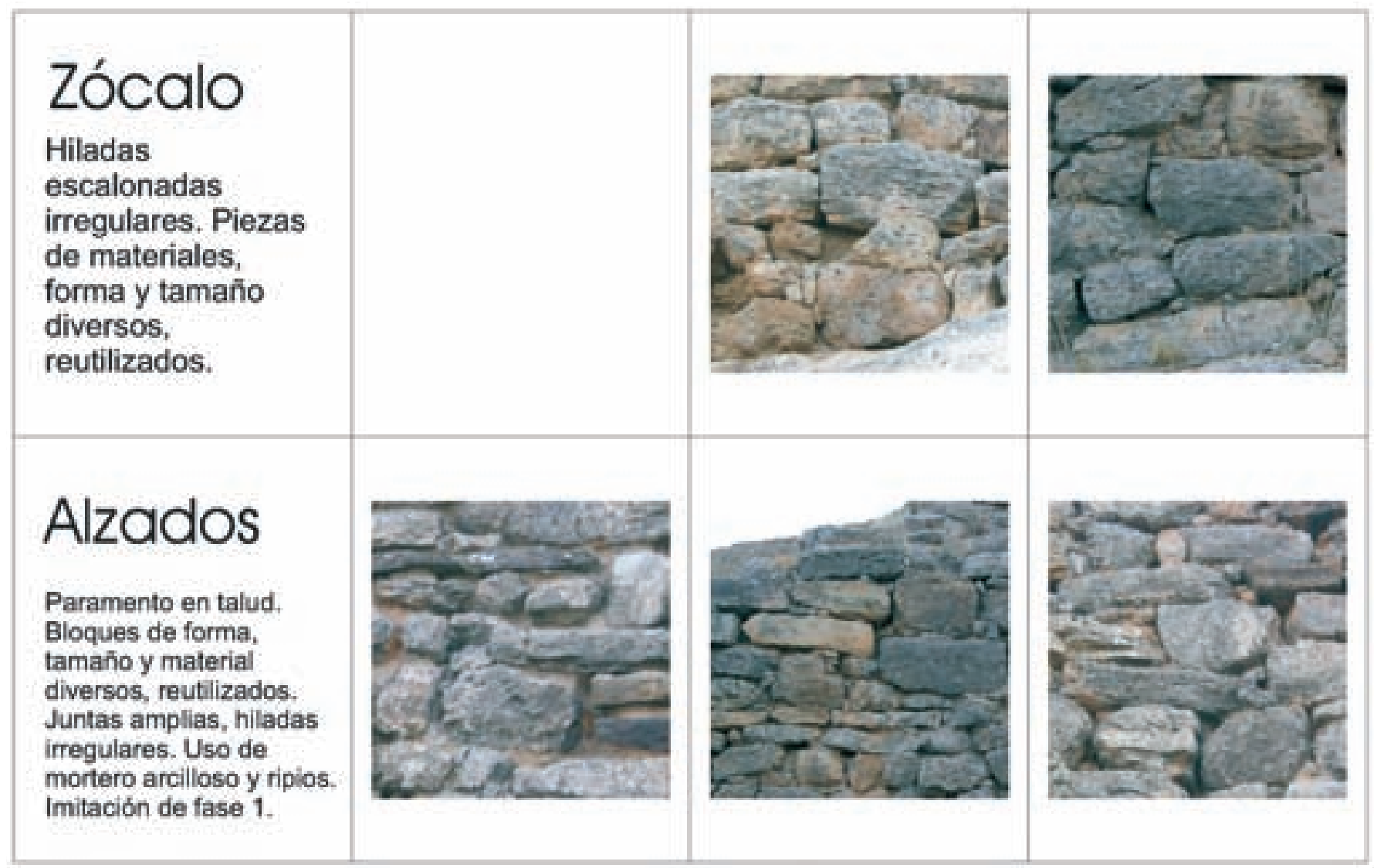

Caracterización constructiva de la Fase 3

su cara exterior, inclinación que llega a ser claramente escalonada en sus hiladas inferiores. El material utilizado en su alzado, es predominantemente la caliza de tipo A, pero también es posible reconocer varias piezas realizadas en caliza de tipo B. La morfología y el tamaño de los bloques utilizados son sumamente variables, pudiendo distinguirse grandes bloques tabulares, bloques rectangulares, trapezoidales, lajas, etc., lo cual, unido a la presencia de algunas piezas engatilladas sin función aparente, nos lleva a pensar en que se trata de piezas mayoritariamente reutilizadas. El trabajo de talla realizado para el ajuste de los bloques parece nulo, siendo muy frecuentes los huecos y grandes juntas selladas con mortero arcilloso y ripios. Como consecuencia de todo ello las hiladas presentan perfiles muy sinuosos y quebrados, llegando incluso a solaparse entre ellas por la presencia de bloques de alturas muy diferentes.

El pequeño recrecido del torreón del sector $\mathrm{B}$ atribuido a esta fase no presenta rasgos técnicos o materiales reseñables, salvo la irregularidad de su fábrica y la evidente reutilización de materiales en ella. La única cuestión interesante que presenta esta pequeña refacción se refiere al, aparentemente anómalo, límite vertical de su extremo este. Una vez comprobada su exacta posición en planta, dicha circunstan- cia se explica por la necesidad que sus constructores tuvieron de enjarjar el nuevo paramento con la obra del muro de división interna del torreón, todavía en pie en este momento, correspondiente a la segunda fase.

El último de los elementos atribuible a esta tercera fase, como adelantábamos, se corresponde con una profunda reforma llevada a cabo en el sector C, reforma que supuso la refacción de un tramo importante del lienzo exterior de la muralla y la construcción de un nuevo torreón, amortizando las estructuras correspondientes al de la fase anterior.

La fábrica del muro externo reconstruido durante esta reforma evidencia la combinación de bloques y piezas reutilizadas, de buena factura, con otros muy irregulares y sin trabajo de talla aparente, siendo posible reconocer bloques de morfología y dimensiones muy diversas. No obstante, debe de destacarse que, en lo que a técnica se refiere, esta refacción resulta más cuidada que las descritas hasta ahora para esta fase, ya que aún con notables deficiencias, producidas por la falta de talla de ajuste y la irregularidad de las piezas utilizadas, la articulación del muro trata de imitar a la de la fase primitiva de la muralla. De esta forma, este paramento arranca desde una zona baja, el zócalo, 


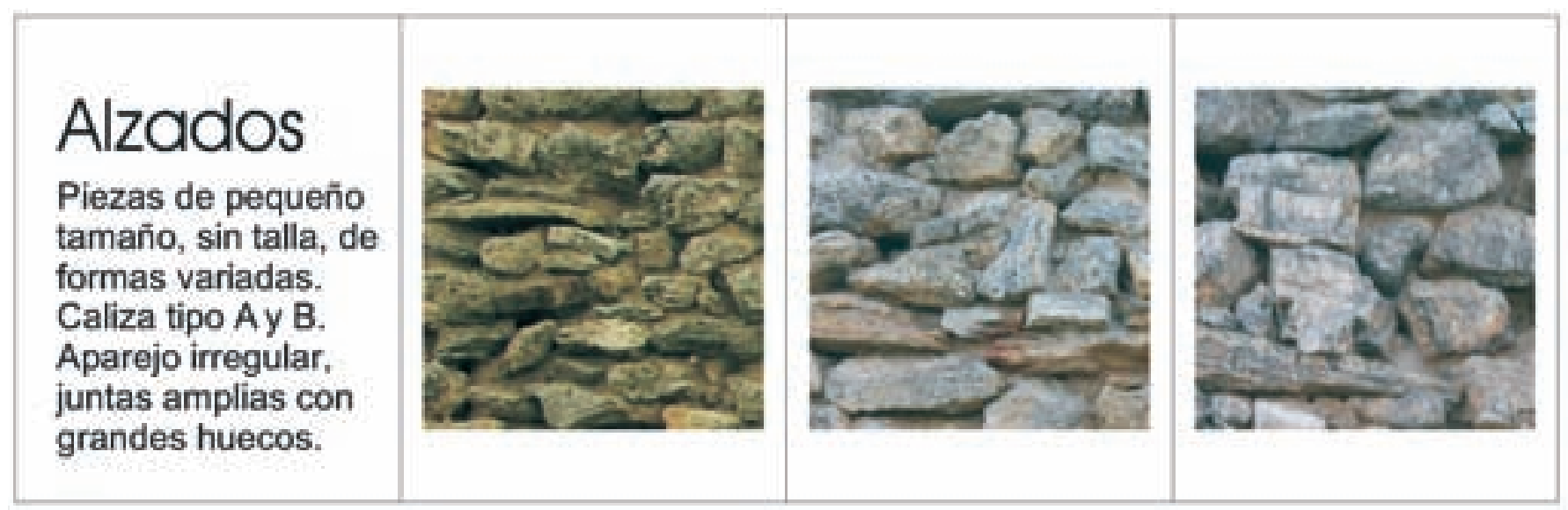

Caracterización constructiva de la Fase 4

compuesto a base de bloques trapeciales, rectangulares e, incluso, poligonales, en los que se utilizó tanto la caliza de tipo A como la B. Los bloques son, en cualquier caso, muy irregulares entre sí, hasta el punto de que resulta difícil identificar hiladas concretas. La zona intermedia, que denominábamos hiladas de regularización en el paño original, también está aparejada a base de lajas y pequeños bloques tabulares, pero ni su tamaño, ni su talla o colocación alcanzan la calidad observada en ellas. Por lo que respecta al aparejo de la zona alta, el alzado propiamente dicho, también trata de recordar el buen aparejo rectangular original utilizando bloques de mayor tamaño y mejor talla, todos ellos reutilizados, lo que hace posible reconocer hiladas aunque muy irregulares. Pese a todo, las juntas son forzosamente muy amplias y fue necesaria la utilización de gran cantidad de mortero arcilloso, muy lavado en todo el paño, y abundantes ripios.

Durante esta misma reforma el torreón primitivo fue sustituido por otro más estrecho y largo que aprovecha, parcialmente las estructuras anteriores. Técnicamente, los paramentos correspondientes a este nuevo torreón se levantaron utilizando una mampostería muy irregular, compuesta generalmente por piezas de tamaño medio y pequeño, sin talla alguna, ajustadas entre sí por medio de gran cantidad de ripios y mortero.

\section{Fase 4}

En la cuarta fase incluimos tres pequeños lienzos conservados en el sector B, dos de ellos correspondientes a reparaciones del paño externo del torreón y, el tercero, a una simple reparación de la muralla ubicada el la zona más oriental del sector. Es posible que estos paños perteneciesen a una misma reparación, ya que desde el punto de vista estratigráfico ocupan posición semejante, pero es un extremo imposible de precisar en el estado actual de la obra, ya que se encuentran físicamente separados por un gran derrumbe del paramento externo de la muralla.

Desde el punto de vista técnico resultan similares, puesto que en los tres casos la reparación se efectuó utilizan-

\section{Alzados \\ Piezas de tamaño pequeño y medio, mayores en las zonas bajas. Materiales diversos, mayoritariamente reutilizados. Disposición irregular, sin hiladas.}

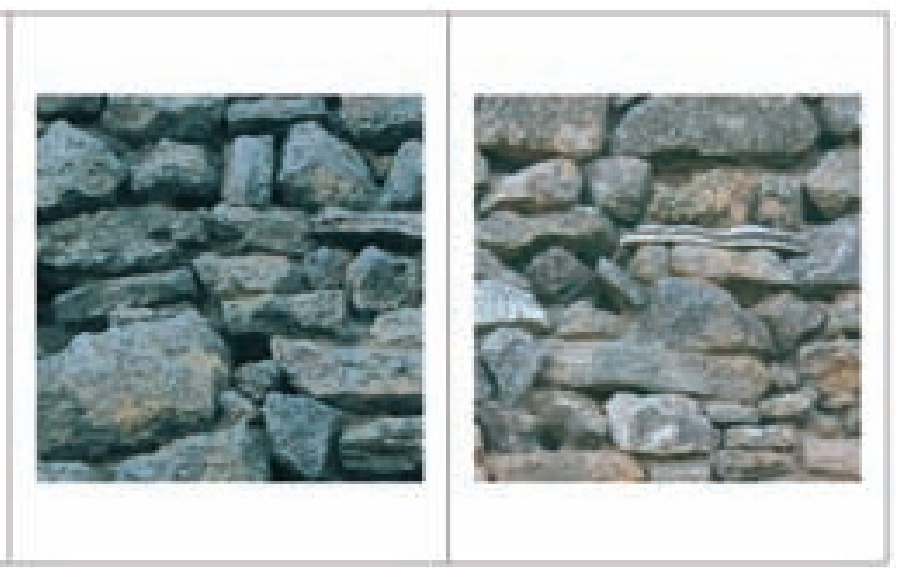

Caracterización constructiva de la Fase 5 
do generalmente piezas de tamaño pequeño, sin talla y de formas muy variadas, dispuestas sin ningún tipo de orden. Por ello, la presencia de juntas gruesas e, incluso, de grandes huecos es lo habitual en la cara externa de estos paños.

\section{Fase 5}

Dentro de esta nueva fase se incluyen dos nuevas reparaciones detectadas en el paramento exterior del torreón del sector $\mathrm{B}$, la primera, más limitada en extensión, afecta parcialmente a su zona media, mientras que la segunda afecto a toda la zona alta del mismo. Evidentemente, la primera es anterior en el tiempo a la segunda, pero optamos por incluirlas es una misma fase con la intención de simplificar esta síntesis.

La diferencia temporal se refleja en las características técnicas de ambas reparaciones, que presentan diferencias sustanciales. La más antigua fue construida utilizando bloques y lajas sin apenas talla de tamaño pequeño o medio, alguno de ellos claramente reutilizado. La disposición de estos bloques resulta completamente aleatoria y sólo la presencia de algunas lajas permite reconocer en él alguna línea horizontal. El recrecido más reciente utiliza también blo- ques y algunas lajas muy irregulares y sin talla, pero se advierte, al menos, una selección de los mismos en función de su posición en el alzado. Así en su parte baja, en el asiento sobre las unidades inferiores, se utilizaron bloques de tamaño medio y grande, mientras que la zona alta se construyo a base de piezas de tamaño pequeño. La disposición de las piezas es en ambos casos muy irregular, si bien la presencia de los grandes bloques de la zona baja ayuda a intuir cierta organización en tres bandas muy irregulares.

\section{Fase 6}

Pertenecen a esta fase dos nuevos elementos: un nuevo torreón, situado parcialmente sobre la posición del torreón original del sector $\mathrm{B}$, y un muro interior, que discurría de forma, más o menos, "paralela» a la muralla. No disponemos de la unión física de ambas construcciones, pero a tenor de lo conservado resulta evidente que las dos formaron parte de un mismo proyecto de remodelación de un amplio sector del sistema defensivo de la ciudad.

La conservación de las estructuras correspondientes al torreón es muy deficiente e, incluso, han llegado a desaparecer por completo en la mayor parte de su planta. En lo

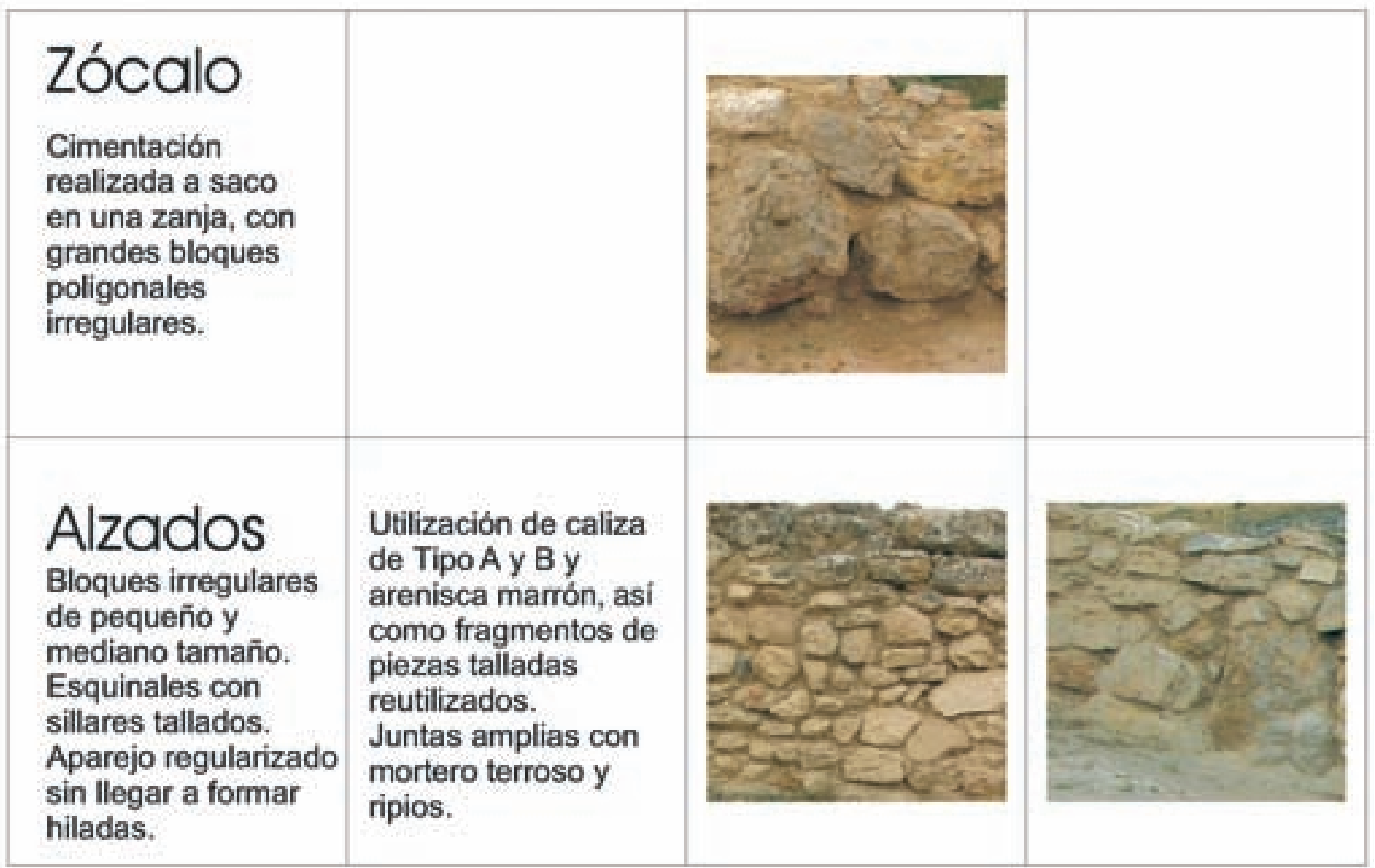




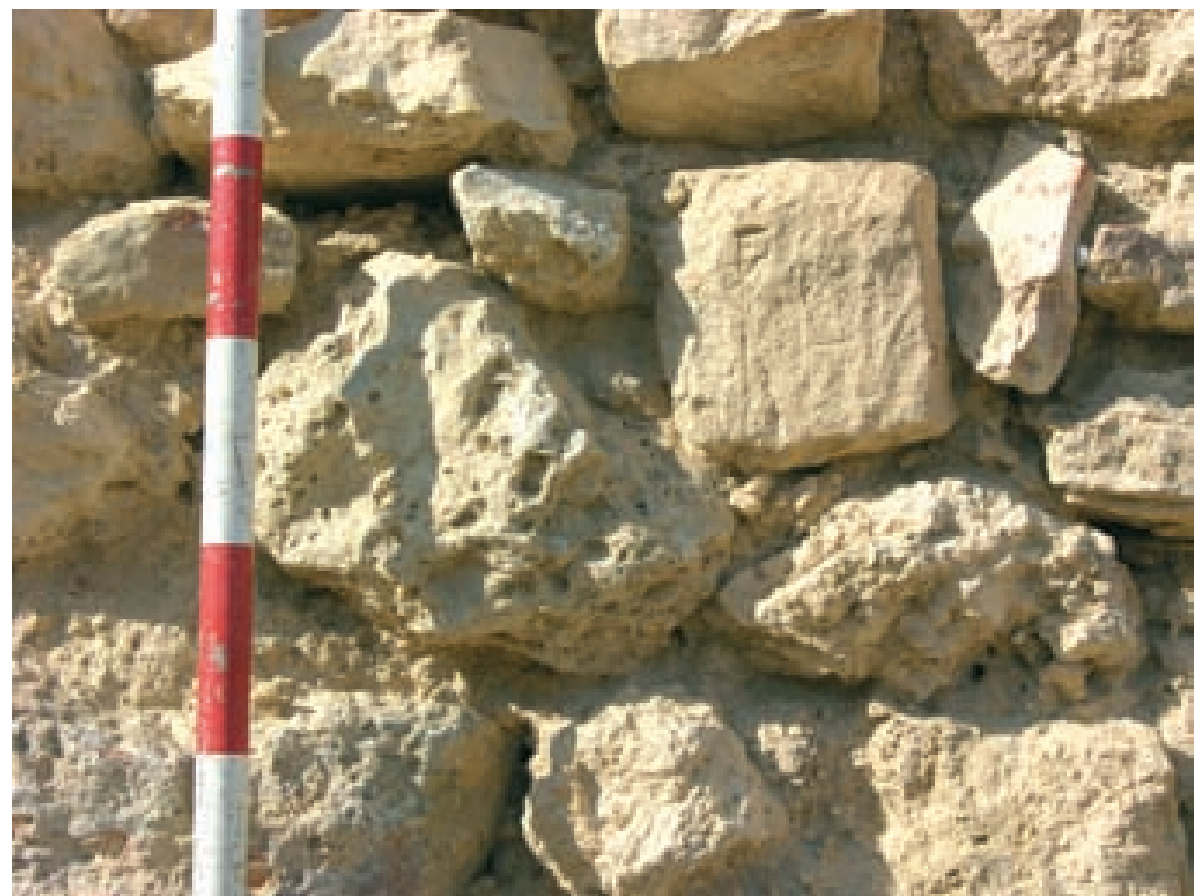

conservado, que se limita a su esquina oriental interna, se aprecia que su construcción no se apoya sobre las estructuras antiguas, sino que lo hace directamente sobre una serie de rellenos que habían amortizado el antiguo torreón con anterioridad.

Constructivamente, las dos hiladas conservadas muestran la utilización de bloques muy irregulares en forma y tamaño, irregularidad que sólo es paliada en la ejecución de la mencionada esquina, donde se utilizaron, seguramente por ser la hilada de asiento, dos grandes bloques bien tallados, de los que sólo conservamos uno.

En cuanto al muro interno pueden distinguirse dos zonas diferenciadas en su estructura: la zona de cimentación y el alzado propiamente dicho. La cimentación se construyó realizando una trinchera sobre los rellenos y colocando sobre la misma una serie de grandes bloques poligonales, que por su morfología e irregularidad parecen haber sido colocados tal y como se extrajeron de la cantera. Sobre ellos, el muro fue levantado utilizando, preferentemente, piezas de tamaño pequeño, entre las que podemos encontrar algunos bloques mayores de forma aislada. En todos los casos se trata de bloques muy irregulares y sólo es posible observar trabajo de talla en algunas pocas piezas reaprovechadas. Por todo ello las juntas son gruesas y la utilización del característico mortero terroso y los ripios muy abundante. En lo referido a la disposición de los bloques resulta en general deficiente e irregular, aunque en alguno de sus tramos llegan en ocasiones a marcarse algunas bandas, más o menos regularizadas. Un aspecto importante con respecto a este muro tiene que ver con sus materiales de construcción, En él se utilizó fundamentalmente la caliza de tipo A combinada con algunas piezas sueltas de tipo B, pero, además, pudimos documentar también la utilización de unos pocos bloques de arenisca, en alguno de los cuales es posible todavía reconocer el trabajo de talla.

\section{Fase 7}

Incluimos en esta fase dos obras bien distintas, por un lado una simple reparación realizada a nivel de cimientos en el torreón de la fase $6 \mathrm{y}$, por otro, una importante readecuación de la muralla llevada a cabo en la zona oriental del sector C. Obras ambas que, a pesar de su diferente trascendencia para el sistema defensivo, comparten una importante cuestión técnica, puesto que en las dos se utilizó como elemento aglutinante el mortero de cal.

Con respecto a la reparación de los cimientos del torreón de la sexta fase poco puede decirse en cuanto a cuestiones técnicas, dado que no contó nunca con un alzado real. No obstante, gracias a su conservación podemos argumentar sobre las dimensiones y morfología del maltrecho torreón.

La obra del sector C correspondiente a esta fase es, como sugeríamos, de mayor trascendencia. Concretamente, la función de esta obra fue la de tratar de solventar el asiento de la muralla en una zona especialmente delicada dada la escasa consistencia que la roca natural presenta en este pun- 


\begin{tabular}{|c|c|c|c|}
\hline $\begin{array}{l}\text { Formado por varios } \\
\text { paños escalonados. } \\
\text { Uso de piezas de } \\
\text { diversos tamaños y } \\
\text { formas, algunas de } \\
\text { ellas escuadradas y } \\
\text { reutilizadas. } \\
\text { Uso de materiales }\end{array}$ & $\begin{array}{l}\text { diversos, caliza tipo } \\
\text { A y B, areniscas } \\
\text { marrones } \\
\text { reutilizadas. Juntas } \\
\text { amplias, } \\
\text { abundantes ripios, } \\
\text { uso de mortero de } \\
\text { cal. }\end{array}$ & & 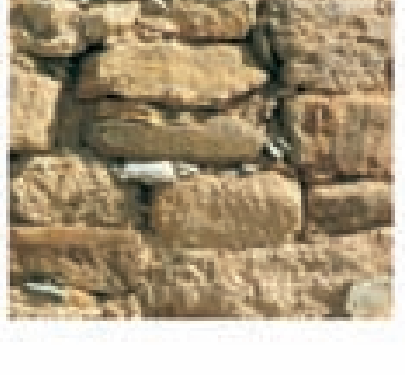 \\
\hline $\begin{array}{l}\text { AlZOClOS } \\
\text { Uso de bloques de } \\
\text { gran tamaño } \\
\text { escuadrados, con } \\
\text { talla visible, } \\
\text { posiblemente } \\
\text { reutilizados. } \\
\text { Utilización de caliza } \\
\text { a y arenisca marrón. }\end{array}$ & $\begin{array}{l}\text { Utilización de } \\
\text { mortero de cal en } \\
\text { las juntas. }\end{array}$ & 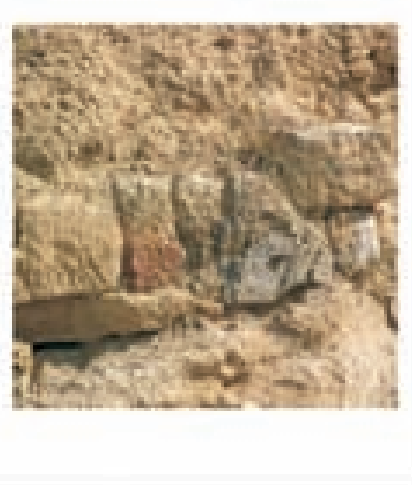 & 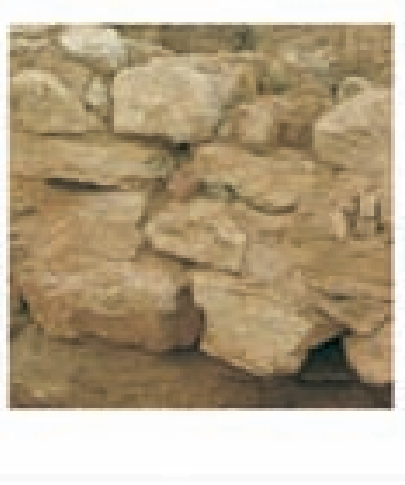 \\
\hline
\end{tabular}

Caracterización constructiva de la Fase 7

to. El problema que la reforma trato de paliar sigue vivo en la actualidad, y buena prueba de ello es que la mayor parte de las estructuras a las que nos referimos se siguen desplomando y perdiendo piezas día a día.

La formula utilizada en este momento para tratar de minimizar la inexorable erosión fue la de forrar la débil superficie rocosa con paños de mampostería que, arrancando desde prácticamente el fondo del foso, se superponen en altura hasta alcanzar la cota necesaria para dar asiento al alzado de la muralla. Se reconocen hasta tres de estos paños superpuestos, perfectamente diferenciables por el pequeño retranqueamiento que los separa y que les da el aspecto de pequeñas terrazas. Técnicamente, estos paños se realizaron utilizando piezas muy diferentes en tamaño y forma, pero con la presencia ocasional de grandes bloques rectangulares, sin duda reutilizados. Un aspecto interesante de reseñar es la presencia de algunas piezas, concentradas en el paño más alto, ejecutadas en arenisca. En cuanto a su aparejamiento, la imagen actual es de completa irregularidad, pero un parte importante de dicha imagen debe achacarse, a nuestro juicio, al deficiente estado de conservación.
Sobre la última de estas pequeñas terrazas conservamos un pequeño fragmento de lo que constituiría el alzado de la muralla perteneciente a este periodo. En lo conservado, al menos la primera hilada estaba constituida por bloques de gran tamaño, y en algún caso de buena talla, que muy probablemente haya que considerar como reutilizados. Entre estos bloques destaca una pieza regular de buen tamaño realizada, también, en arenisca. No obstante, el rasgo técnico más destacable de este pequeño tramo de muralla es la utilización de mortero de cal en su construcción.

\section{Fase 8}

A esta fase, la última de cuantas podemos identificar con seguridad, pertenecen dos pequeños arreglos, uno situado en el extremo oriental del sector A y otro en la parte baja de las terrazas del sector $\mathrm{C}$ pertenecientes a la fase anterior. Dichos arreglos no presentan cuestiones técnicas reseñables, estando ejecutados en ambos casos con mampostería muy irregular y sin ningún tipo de regularidad en la colocación de sus bloques, en la que se utiliza un mortero terroso en el que se encuentran fragmentos disgregados de mortero de cal. 


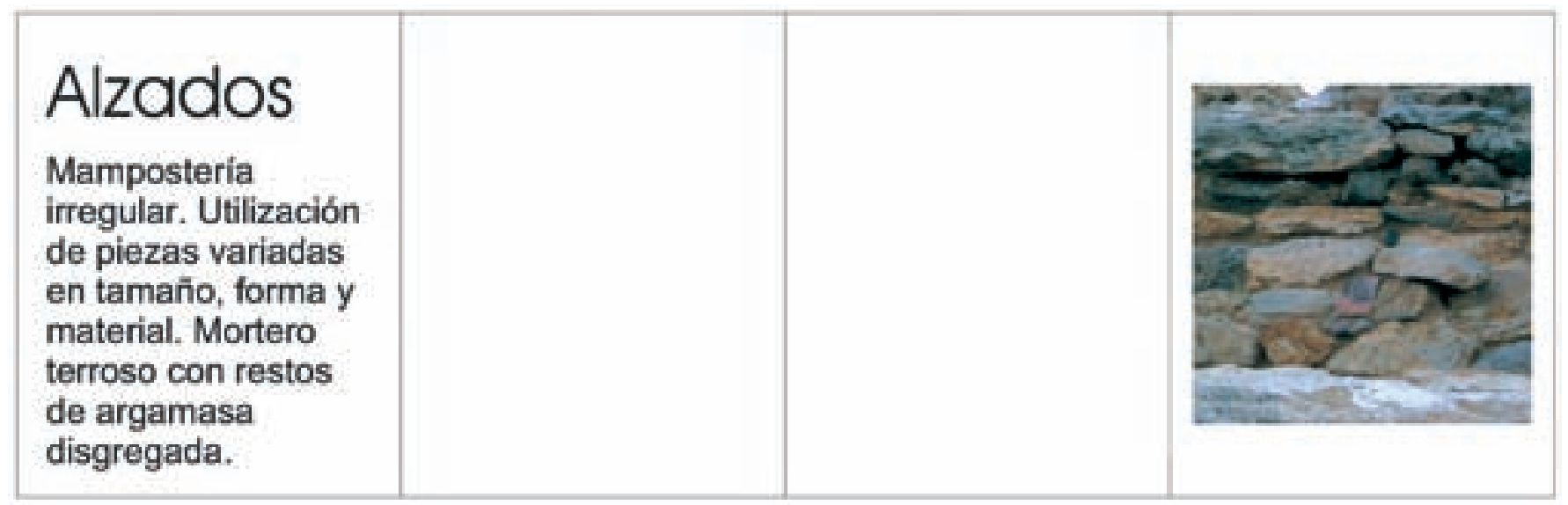

Caracterización constructiva de la Fase 8

\section{EL PROBLEMA DE LA CRONOLOGÍA}

«Uno de los problemas más frecuentes en el estudio de los sistemas defensivos ha sido siempre el de la datación» (ROMEO 2002, p. 153). Con esta frase comienza uno los trabajos más recientes sobre fortificaciones antiguas en la Península Ibérica, pero podríamos haber elegido otras muchas, más o menos acertadas o profundas, referidas a cualquier rincón geográfico del Mediterráneo para iniciar este apartado. Tiene razón, en cualquier caso, el mencionado autor, pues la cronología es uno de los principales problemas de investigación para aquellos que tenemos que enfrentarnos, por una u otra circunstancia, al estudio de este tipo de construcciones defensivas.
No es de extrañar, por tanto, que para resolver este problema los estudiosos de la poliorcética clásica hayan recurrido a muy diferentes recursos a la hora de tratar de ubicar temporalmente sus reflexiones sobre el tema, recursos que van desde la imprescindible estratigrafía de subsuelo, la metrología o, por señalar algún caso extremo, la paleografía de las marcas de cantero. Todo tipo de argumentaciones disponibles han sido utilizadas con mayor o menor éxito y credibilidad. Pero, sin duda, el núcleo interpretativo estrella ha sido, y todavía sigue siendo, el de las cronotipologías.

Creemos, sinceramente, que el papel de el tipo de dataciones cronotipológicas ha sido importantísimo en el avance de nuestro conocimiento sobre las fortificaciones

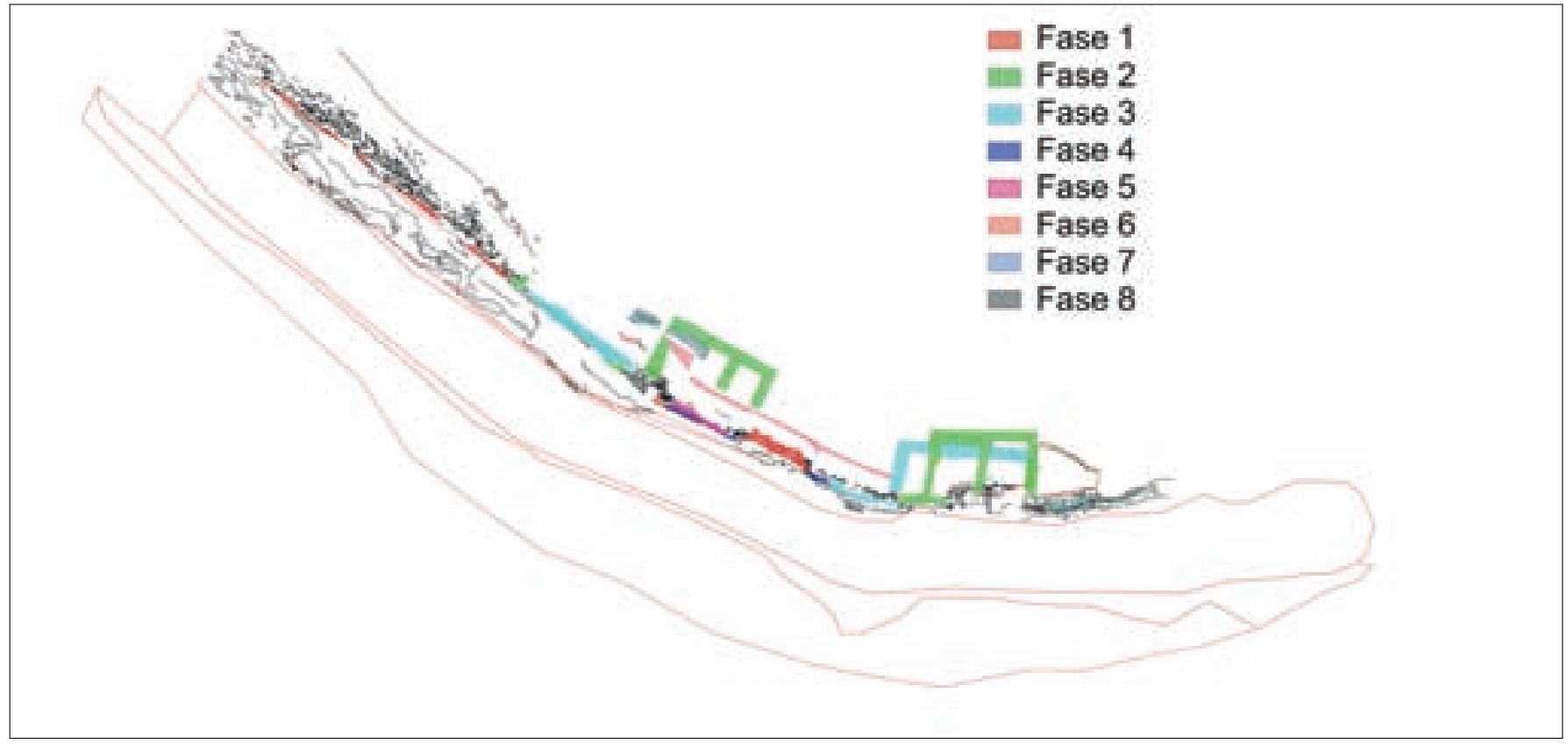

Planta de fases constructivas 
antiguas y que se trata de un tipo de argumentación plenamente vigente y válida en el futuro aunque, desgraciadamente, su excesiva vinculación, en unos casos, a presupuestos metodológicos obsoletos y, en otros, a su deficiente utilización, hace que el manejo de esta vía interpretativa resulte siempre demasiado compleja y no siempre satisfactoria. No siendo de extrañar algunas críticas parciales realizadas, curiosamente, por autores que luego, indefectiblemente, deben recurrir obligatoriamente a ella para justificar sus opiniones.

El caso de la muralla de Contrebia Leukade podría considerarse un ejemplo «tipo» de las controversias que esta clase de aproximaciones cronológicas ha generado, ya que historiográficamente podemos encontrar dos posturas bien diferenciadas: la que considera que el origen del sistema murado de Inestrillas es consecuencia de la presencia romana, opinión que ya defendió Taracena, y la que propone cronologías más altas relacionadas, quizás, con influencias también mediterráneas pero de distinto signo.

Es por ello que, también nosotros, tratando de aportar algo de luz a la problemática cronológica de la muralla de Contrebia, aunque centrándonos exclusivamente en su flanco meridional, nos hemos visto obligados a recurrir a los argumentos disponibles que son en este caso de carácter estratigráfico y cronotipológico, si bien debemos reconocer que, gracias a la lectura estratigráfica de sus alzados, partimos con la ventaja de conocer la cronología relativa de cada uno de sus elementos compositivos.

No pretendemos, no obstante, aproximarnos a la cronología de todas y cada una de las fases que hemos reconocido en la lectura, trabajo que excede ampliamente los objetivos de este estudio, pero sí al menos asentar las bases cronológicas, concretamente la de sus dos etapas iniciales, de un sistema defensivo que estructuralmente permaneció «vivo» durante un milenio y, de paso, intervenir, de nuevo, en la mencionada polémica historiográfica.

\section{Las estratigrafías del subsuelo}

Contamos con datos pertenecientes a dos únicas unidades estratigráficas relacionadas con las fases iniciales de la muralla: la primera situada en la zona de la puerta y la segunda correspondiente a la amortización de la torre del sector C. Se trata de unidades inéditas y cuyos datos requerirán una mayor elaboración en un futuro, pero desde este análisis inicial ofrecen ya indicios importantes para los elementos arquitectónicos relacionados estratigráficamente con ellas. Nuestro argumento a la hora de interpretarlas cronológicamente es simple, pues se basa en la presencia o ausencia de producciones cerámicas de barniz negro itálico, cuya importancia como elemento cronológico ha sido recientemente puesta de relieve por varios autores (ROMEO 2002, p. 173, MORET 2003, p. 161). En nuestra zona, contamos además, con cierta seguridad cronológica sobre el momento de llegada de dichas producciones cerámicas gracias a la extensa colección proporcionada por las estratigrafías de Graccurris (Alfaro) (Hernández Vera y NúNEEZ 1998), momento que podríamos situar, desde los datos actuales, en el primer cuarto del siglo II a. C.

En el primer caso, la unidad asociada a la puerta, los materiales recuperados son escasos pero, al parecer incluyen fragmentos de barniz negro y además tiene una serie de relaciones estratigráficas del mayor interés, puesto que se adosa, y por lo tanto es posterior, a la construcción de la torre que defiende el flanco meridional de la puerta, correspondiente en nuestra lectura a la segunda fase de la misma. No es mucho, lo que esto significa para la datación de esas primeras fases que tratamos de ubicar temporalmente, pero al menos indica que la segunda torre de la puerta, la que la flanquea por el oeste, se construyó en época republicana.

La unidad excavada en la torre del sector $\mathrm{C}$ de la muralla, por el contrario, únicamente proporcionó materiales cerámicos de tipo celtibérico, aunque no muy abundantes, por lo que, quizás, la construcción de estas torres, correspondientes a la segunda fase de la muralla, debamos situarla en un momento en el que la presencia romana no se encontraba plenamente desarrollada en nuestra área.

\section{Los argumentos cronotipológicos}

El volumen de la bibliografía que se ocupa de lo aspectos tipológicos relacionados con los sistemas defensivos antiguos resulta inabordable en este tipo de estudios, por lo que nos hemos limitado a tratar de resumir lo aportado por las síntesis más recientes sobre los elementos que consideramos más característicos y significativos de nuestra muralla.

\section{Fosos}

El foso no puede considerarse un elemento imprescindible del sistema defensivo, sino un simple complemento de la muralla, por lo que quizás pudiera parecer que los comentarios tipológicos que le dedicaremos ahora podrían estar fuera de lugar en este estudio. Sin embargo, y como podrá comprobarse en lo que sigue, se trata de un elemento muy considerado desde el punto de vista de este tipo de análisis y, además, la enorme entidad del foso que defiende fachada meridional de la muralla de Inestrillas hace obligatorio que nos refiramos a él.

Como señalaba A. J. Lorrio hace ya algunos años (1997, p. 88), la información de la que disponemos sobre los fosos defensivos en territorio celtibérico es, todavía, muy reducida al encontrarse en la mayor parte de los casos 
colmatados. En cualquier caso, la presencia de fosos en las poblaciones del área celtibérica correspondientes a la Segunda Edad del Hierro estaría bien representada, siendo al parecer más frecuentes «y de mayor entidad entre los poblados situados en territorio aragonés» (IBIDEM.).

La sección de los fosos presenta generalmente perfiles en $\mathrm{U}$ y su anchura parece oscilar entre los 4 y los, increíbles, 60 metros que se atribuyen al foso del poblado de El castillo de Villarroya (IBIDEM.). Por lo que respecta a su profundidad es difícil de determinar por las razones aludidas, si bien A.J. Lorrio señala un límite de 7 metros para el más profundo de los conocidos en la actualidad. El mismo autor señala más adelante que, entre los fosos que defendieron a las ciudades celtibéricas, destaca claramente el de Contrebia Leukade, habida cuenta de su longitud, anchura, profundidad y volumen de obra (IBIDEM., p. 90; HERNÁNDEZ VeRA 1982, p. 122 y ss.).

Para las áreas ibéricas más cercanas, se han apuntado recientemente, algunos argumentos tipológicos que también conviene tener en cuenta a la hora de ubicar cronológicamente el sistema defensivo que nos ocupa, destacando entre ellos el que tiene que ver con la anchura de los fosos pertenecientes a las defensas de poblados ibéricos del Valle Medio del Ebro. Según la propuesta de Romeo (ROMEO 2002, p.157 y ss.) hay que considerar dos grupos bien diferenciados: el primero caracterizado por fosos con anchuras de entre 5 y 10 metros y el segundo por fosos de achuras que «se acercan o superan la veintena de metros». Lo más importante, en cualquier caso, es que dicha diferenciación, según el autor de la propuesta, contiene una significación cronológica, ya que «los fosos con anchuras de cerca de diez metros pertenecen a yacimientos estrictamente ibéricos, mientras que los pertenecientes al segundo grupo aparecen en yacimientos intensamente romanizados» (IBIDEM. p. 162).

Las bases argumentales utilizadas para tal periodización de carácter tipológico no son en este caso estratigráficas, sino que tienen que ver con las supuestas diferencias en la forma de afrontar el combate por parte de los pueblos ibéricos y de los itálicos. Los primeros, a juicio de Romeo, caracterizados por «un rechazo generalizado de las armas arrojadizas» y los segundos, por el contrario, «dotados de este tipo de armas» (IBIDEM.).

Por su parte Henri Tréziny, refiriéndose a los fosos que defendieron las fortificaciones griegas del mediterráneo occidental en época clásica, comenta "Ce qui est sûr, c'est que la plupart des fossés connus sont très proches de la muraille: ils avaient pour but de gêner l'assaut direct, et notamment l'utilisation des béliers et le creusement des sapes. Seul le fossé A de l'Euryale est suffisamment éloigne du fort pour avoir pour fonction principale d'eloigner les lithobo-

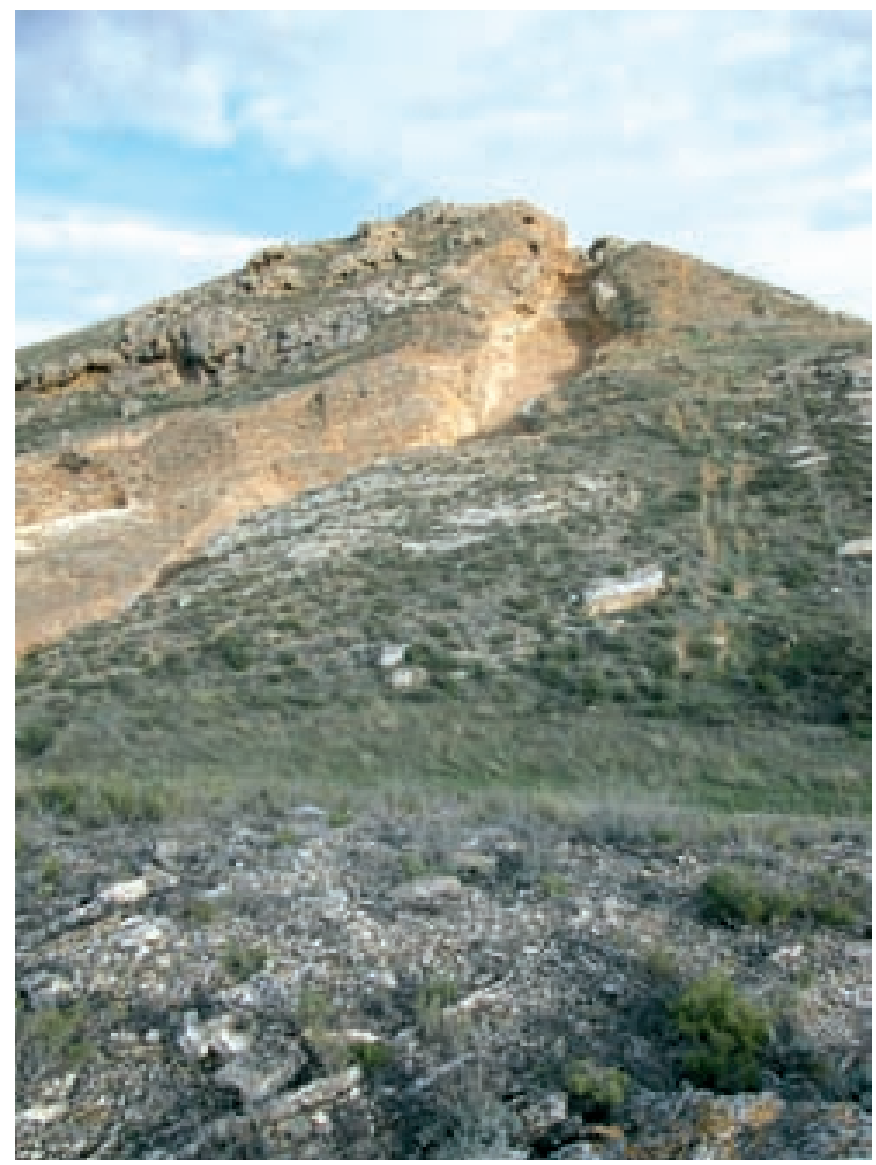

Vista del foso desde el sur

les, mais on le date généralment assez bas dans le IIIe s». (TRÉZINY 1999, p. 260).

De todo ello, parece lógico concluir, en primer lugar, que tanto la anchura como la posición, más o menos, alejada de los fosos con respecto a la muralla que defienden, estaría en relación directa con la utilización, por parte de las tropas atacantes, de unos tipos concretos de máquinas de guerra y, en segundo lugar, que se trataría en todo caso de innovaciones poliorcéticas desarrolladas durante el período helenístico en el occidente griego o bien, refiriéndonos al caso hispano, achacables exclusivamente a la influencia directa de los ejércitos de Roma.

Resulta necesario en este punto recordar, una vez más (HERNÁNDEZ Vera 2003, p.72), que el foso que defiende el flanco meridional de la ciudad de Contrebia, tallado al pie mismo de la muralla y con una anchura de entre 7 y 9 metros, no respondería en absoluto a las características bélicas correspondientes al tipo de fosos apuntados como tardíos, a pesar de lo cual algunos autores, entre ellos sorprendentemente el propio Romeo (2002, p. 167 y s.), mantienen propuestas cronológicas avanzadas para el origen del sistema defensivo de Contrebia, insistiendo en la existencia de una influencia claramente itálica en su construcción. No son, no 
obstante, las características constructivas del foso las que determinan esta postura historiográfica, puesto que la comentada propuesta de datación tardía de las defensas de Contrebia se sustenta exclusivamente en otra cuestión tipológica, referida en concreto a la estructura de la muralla propiamente dicha y en la que luego nos centraremos, obviando sorprendentemente sus propios argumentos cronotipológicos referidos a los fosos.

En este sentido, algunas de las pocas cuestiones que podemos confirmar con rotundidad, desde el análisis estratigráfico de los alzados de la muralla de Contrebia, es que la excavación del foso que la defiende por el Sur determinó, sin lugar a dudas, el trazado de las defensas de este sector de la ciudad en todas sus fases, como señalábamos en su caracterización constructiva, y que lógicamente su excavación debió de ejecutarse de forma previa, o bien de forma paralela, a la más antigua de las mismas.

Las cifras de obra de este foso son todavía provisionales y en la actualidad sabemos con certeza que alcanzan un mayor volumen, pero utilizando sencillamente las magnitudes manejadas desde finales del pasado siglo, basta señalar que con sus 672 metros de longitud y sus más de 40.000 metros cúbicos de roca excavada (Hernández Vera 1982, p. 122

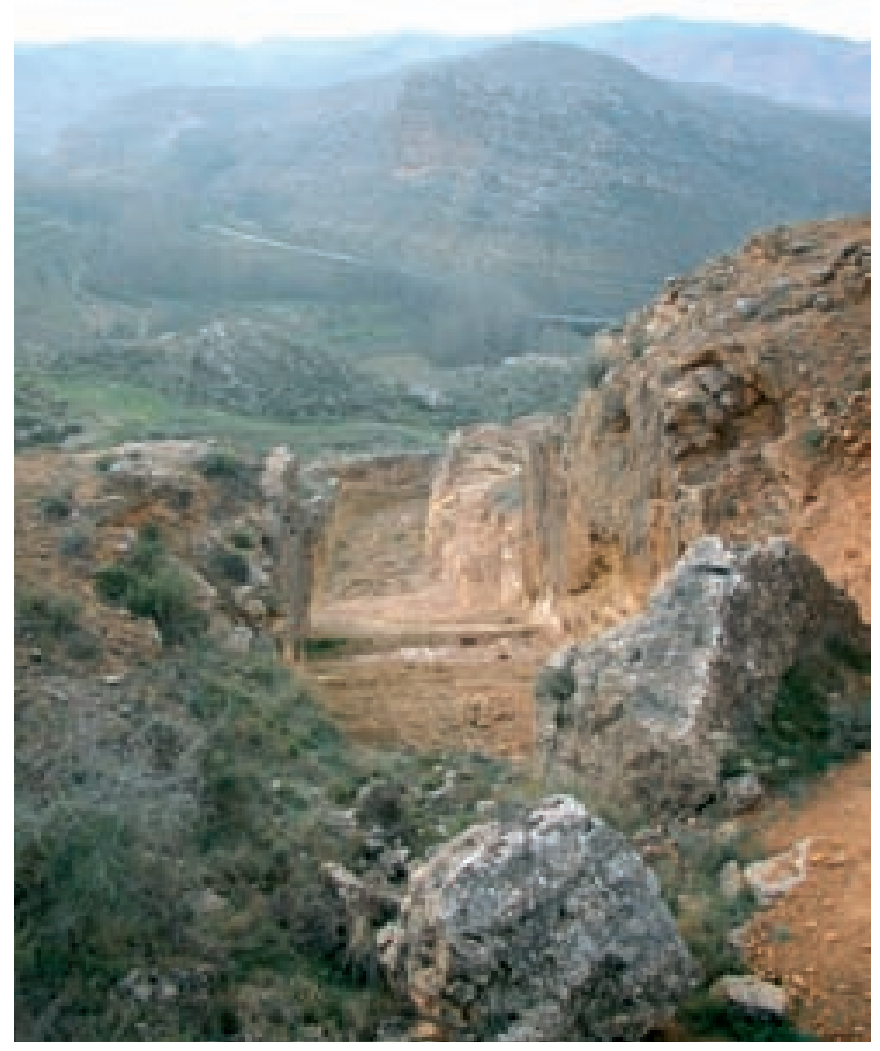

Detalle de la caja del foso y s.) se trata de una obra única en Hispania y, aún teniendo en cuenta cualquiera de las posibilidades cronológicas apuntadas hasta el momento para su construcción, podría calificarse de colosal. Desde esta perspectiva, nos parece necesario retomar una de las reflexiones de Pierre Moret (2003, p. 162) planteadas en su estudio más reciente sobre las defensas ibéricas tardías: "Chacun sait que c'est en période de paix ou d'accalmie, quand les Etats ou les cités diposent de temps, de trésorerie et de bras disponibles, que l'on bâtit des enceintes urbaines. En temps de guerre, sous la pression des événements et dans l'urgence des périls, une fortification complexe (bâtie en pierres de taille, munie de tours et éventuellement complétée par un avant-mur ou un fossé) était un projet irréalisable, compte tenu des ressources techniques des Anciens». Sólo restaría preguntarnos: ¿En que momento se dieron todas estas circunstancias favorables, para que los habitantes de la ciudad de Contrebia pudiesen acometer, con garantías, la excavación este impresionante elemento del sistema defensivo de la ciudad?

Para finalizar el apartado dedicado a los fosos es obligado recordar que, si tenemos en cuenta las posturas más recientes (HOURCADE 2003, p. 303), el foso no parece un elemento defensivo demasiado bien representado en el grupo de murallas atribuidas a las ciudades romanas de la Hispania de época republicana y que: «Leur existente n’a, bien évidemment, de sens que dans les cas des sites de plaine, ou de plateau, où un très fort escarpement ne rend pas inutile des tels aménagements» (IBIDEM.). Contrebia por su superficie ocupada, calculable en un mínimo de $12 \mathrm{Ha}$. (HerNÁNDEZ VERA 2003, p. 62), puede considerarse sin duda una autentica ciudad en nuestro contexto, cuenta con foso $y$, desde luego, no se encuentra ubicada en llano, baste para corroborarlo apuntar que, en el tramo de foso analizado en el presente estudio, la diferencia de cota entre la puerta occidental y el torreón del sector C es de 25 mts.

\section{Los trazados}

Refiriéndonos a los trazados generales de los recintos amurallados, ya sea en área celtibérica o ibérica, parece existir un consenso entre los diferentes investigadores que se han ocupado del tema, según el cual se reconoce una característica común a la gran mayoría de los recintos amurallados hispánicos: «la influencia determinante del lugar elegido» (LORRIO 1997, p. 71), o lo que es lo mismo su adecuación, en ocasiones, absolutamente determinante, a la topografía natural del solar sobre la que se implantaron estos poblados y ciudades.

Esta influencia de la topografía sobre el trazado adoptado por las murallas supone de hecho, en muchas ocasiones, que los lienzos únicamente defiendan los flancos más desprotegidos topográficamente, confiando la defensa del 
resto del perímetro a las alturas y cortados naturales. Es el caso de muchos poblados y ciudades prerromanos de la Península Ibérica, incluida también la propia Contrebia Leukade, y parece oportuno señalar que recientemente se ha propuesto, concretamente para el caso de Olerdola, que se trataría de una concepción poliorcética «plus proche des traditions ibériques que des normes de l'urbanisme romain» (MORET 2003, p. 166, n. 4).

La gran mayoría de los trazados de las fortificaciones prerromanas de la Península Ibérica ofrecerían, desde esta misma perspectiva, «une conception rudimentaire de l'architecture defensive» (MORET 2002, p.189) y sólo unos pocos encintados hispánicos, asociados en principio a distintas influencias mediterráneas (IBIDEM. p.209 y ss.), se alejarían de la comentada tendencia general, evidenciando trazados cuyo diseño superaría la mera adecuación a los condicionantes topográficos.

El sector de la muralla de Contrebia analizado en el presente trabajo cuenta, desde su primera fase, con una planta simplemente quebrada cuyo trazado parece ajustarse a los cambios de pendiente naturales, circunstancia tipológica muy generalizada, como avanzábamos, y carente de una significación cronológica precisa. No obstante, los recientes trabajos de excavación llevados a cabo en la fachada Norte de la ciudad, la menos protegida por la topografía natural, han puesto al descubierto una serie de paños correspondientes a la muralla prerromana de la ciudad que presentan una disposición quebrada que nada tiene que ver con la adecuación topográfica y que parecen apuntar a la existencia de un tramo "acodado» en esta zona del sistema defensivo. Además, algunos de estos paños, tanto por la morfología como por la disposición técnica de sus bloques, pueden ponerse en relación directa con las características constructivas descritas para nuestra primera fase, por lo que, aún de forma indirecta, esta circunstancia aporta nuevos argumentos para solventar el problema que nos ocupa.

Sobre las murallas «acodadas» o "en cremallera», como se las conoce en la historiografía francesa, A.J. Lorrio (1997, p. 76), señalaba hace algunos años que se trata de una de las innovaciones introducidas en la poliorcética celtibérica a lo largo de la Segunda Edad del Hierro y que su origen, o inspiración, debía buscarse en los amurallamientos griegos de época helenística.

Aunque existen otras hipótesis con respecto al origen último de esta innovación poliorcética ${ }^{6}$, la que ha generado

\footnotetext{
${ }^{6}$ Nos referimos a la conocida hipótesis según la cual estos muros en cremallera tendrían su origen en la arquitectura militar púnica (BARRECA, F., La città punica in Sardegna, Bolletino del Centro di studi per la storia dell'architettura, 17, 1961, p. 38).
}

más consenso es la propuesta por Yvon Garlan (1974, p. 248 y ss.), quien limitaba la construcción de este tipo de paramentos en las fortificaciones griegas a un período comprendido entre mediados del siglo IV y mediados del III a. C., señalando, más concretamente, el reinado de Filipo II de Macedonia como el punto de partida para este tipo de defensas. Conviene recordar, no obstante, que Garlan diferenciaba claramente en su estudio las murallas «à crémaillère» $\mathrm{y}$ las «fauses crémaillères», generadas, estas últimas, por un simple engrosamiento de los muros. A este tipo «falso" pertenecerían algunas defensas hispanas consideradas habitualmente como «acodadas». La diferencia es sustancial, puesto que desde el punto de vista cronotipológico no tienen, en opinión del propio investigador francés, la misma significación. En cuanto a la cronología, apuntada de forma genérica para las murallas ibéricas que presentan características similares a las descritas se ha planteado, igualmente, una datación situada a lo largo de los siglos IV y III a. C. (LORRIO 1997, p. 76).

La función táctica de estos paños dispuestos oblicuamente «en cremallera», según se desprende de las fuentes y los modelos helenísticos, fue la de incrementar la capacidad de ataque de los defensores sobre el flanco desprotegido de los posibles atacantes - el derecho- por lo que los «codos» que unen los diferentes tramos de este tipo de murallas deben orientarse en esa dirección. En las fortificaciones hispánicas que presentan una disposición semejante en sus trazados, este simple principio funcional no se cumple de forma estricta, y podemos identificar con seguridad configuraciones absolutamente rigurosas con este concepto defensivo, caso por ejemplo del castro de Castilviejo de Guijosa (MORET, 1991, p. 36), o lugares en los que el «codo" o «retranqueo» de las murallas se dirige al flanco contrario (ROMEO, 2002, p. 174), modelo este último en el cabría integrar el sector en "cremallera» reconocido en la muralla de Contrebia. Lo que no nos parece tan evidente es que esta particular configuración de algunos de los trazados de muralla hispánicos deba achacarse exclusivamente a la ausencia de influencias mediterráneas (IBIDEM.).

En última instancia, nos parece absolutamente necesario recordar que esta manera de trazar las defensas amuralladas de un poblado o de una ciudad no parece poder asociarse, por el momento, a los recursos poliorcéticos implantados en la Península ibérica por los ejércitos itálicos.

\section{Las cuestiones técnicas}

Dentro del capítulo referido a las cronotipologías propuestas para las técnicas utilizadas en la construcción de los amurallamientos hispánicos de época prerromana, existen varios aspectos de interés en los que la historiografía más reciente ha fijado su atención, aunque si nos centramos en 
las que ahora resultan más útiles para tratar de aportar cronología a las fases más antiguas de la muralla de Contrebia únicamente nos parece oportuno, por el momento, centrarnos en el referido a su estructura interna.

En este sentido, la estructura interna de la muralla de Contrebia, teniendo en cuenta únicamente la correspondiente al sector meridional objeto de este estudio, ha sido incluida por diferentes autores (TARACENA 1942, p.27; ASENSIO 1995, p. 351; LORRIO 1997, p. 79; ROMEO, 2002, p. 167 y ss.) dentro del grupo tipológico de las denominadas «murallas de cajones», atendiendo, eso sí, a las descripciones realizadas exclusivamente desde la observación meramente superficial de sus restos. Como hemos indicado, esta «clasificación» tipológica es, en realidad, la responsable de que la muralla de Inestrillas haya sido considerada reiteradamente, desde la primera publicación de Blas Taracena (HERNÁNDEZ VERA 2003, p. 69), como una construcción de cronología tardía. Datación tipológica que varía significativamente de un autor a otro. Así podemos encontrar posturas «moderadas», como la de Taracena (1942, p. 27), que apuntaban a los dos primeros cuartos del siglo II a.C., y también otras muy drásticas, que proponen cronologías mucho más avanzadas, asociando su construcción incluso al desarrollo de la denominada "Guerra Sertoriana», dentro ya del siglo I a. C. (AsENSIO 1996, p. 35).

Los argumentos tipológicos para la tardía datación de este tipo de murallas «de cajones» no han variado excesivamente desde su formulación a mediados del siglo pasado, $\mathrm{y}$ se centran en una supuesta inexistencia de influjos mediterráneos tempranos en el interior de la Península Ibérica, concepto que a nuestro juicio todavía está por demostrar con pruebas irrefutables, por lo que su introducción en el repertorio poliorcértico ibérico o celtibérico se atribuye indefectiblemente a los ejércitos itálicos responsables de la conquista romana de Hispania.

El debate sobre el origen y difusión de este tipo estructural en las murallas del Mediterráneo occidental, a tenor de las diferentes opiniones que hemos podido recoger, dista mucho de ser un tema de investigación cerrado (TRÉZINY 1996, p. 350 y ss.; 1999, pp. 253 y ss.; ROMEO 2002, p. 168), pero afortunadamente no resulta necesario que abordemos esta espinosa cuestión en el caso de Contrebia, puesto que la reciente excavación de algunos de los sectores del flanco Sur de sus murallas (HERNÁNDEZ VERA 2003, p. 69) nos ha permitido confirmar, sin lugar a dudas, que los supuestos «cajones» descritos por Taracena no son otra cosa que los muros correspondientes a un sistema de torres, o torreones, completamente independientes entre sí. De esta forma, el principal argumento sobre la datación tardía de las murallas de Contrebia se desvanece, y la problemática cronotipológica se imbrica, sencillamente, con el de los elementos de flanqueo, las torres, que trataremos más adelante.

Esto no quiere decir, sin embargo, que la estructura interna de las fases iniciales del sector Sur de la muralla de Inestrilllas, aun cuando consideramos que sería necesario comprobarlo en el resto de los sectores en los que pudieran conservarse paños correspondientes a estos períodos, no puedan describirse manejando elementos característicos de la arquitectura mediterránea antigua y que no revistan interés cronotipológico alguno.

En buena parte de su alzado, concretamente hasta la cota del suelo de las mencionadas torres, correspondientes recordémoslo a la segunda fase que proponemos desde nuestro análisis estratigráfico, la estructura construida de la muralla Sur de Inestrillas podría definirse desde el punto de vista estructural como un analemma (MARTIN 1965, p. 374 y ss.), o lo que es lo mismo un muro de terraza, circunstancia constructiva que no resulta ajena a algunas murallas griegas de occidente, entre las que podríamos recordar el caso del sector nordeste de la muralla de Hipponion - la posteriror ciudad romana de Vibo Valentia- (SÄFLUnD 1935, pp. 87 y ss.; AUMÜLler 1994, p. 241 y ss.; TRÉZINY 1999 , p. 246 y ss.), pero para la que no encontramos ejemplos suficientemente bien descritos en nuestra historiografía más cercana geográficamente.

Desgraciadamente, la discusión cronológica sobre la datación de las murallas «aterrazadas» de Hipponion podría resumir, perfectamente, los problemas de ubicación temporal de los grandes amurallamientos que tratábamos de evidenciar al comienzo de este apartado. Problemas que pueden quedar resumidos en los comentarios del propio Henry Tréziny (IBIDEM. nota 24) en relación con esta muralla de Hipponion: "Les recherches ont porté sur un secteur de rempart au nord-est de la ville. On a identifié quelques traces d'un rempart daté avec quelque vraisemblance vers le fin de l'époque archaïque». Esta cronología arcaica sería la datación propuesta por Aümuller, ya que Säflund proponía para ella una datación del siglo IV a.C., tras "compararla» con la muralla helenística de Kaulonia, ciudad en la que, no obstante, también se documenta «une enceinte archaïque..., ce qui montre bien la vanité des datations purement typológiques» (IBIDEM.).

\section{Torres}

Las torres de flanqueo han sido historiográficamente uno de los elementos más significativos y utilizados desde el punto de la cronotipología de los amurallamientos antiguos, por lo que, una vez demostrada la presencia de torres cuadrangulares en este tramo de la muralla de Contrebia (HernándeZ Vera 2003, p. 70 y ss.), contamos con un 
nuevo argumento cronológico del máximo interés. En cualquier caso es necesario recordar que las torres, o torreones como los denominamos en nuestra lectura, de la muralla Sur de Contrebia pertenecerían a la segunda fase constructiva y que, además, las unidades estratigráficas que cubrían el suelo de una de ellas aportaron únicamente algunos materiales cerámicos de filiación exclusivamente indígena.

Las torres de forma cuadrangular, desde la óptica de las propuestas más recientes (MORET 1996, p. 112 y ss.), aparecerían como complemento defensivo de las murallas ibéricas en el periodo denominado preibérico y su construcción se generalizaría durante los siglos $\mathrm{V}$ y IV a. C. La introducción de estos elementos de flanqueo en el repertorio poliorcético ibérico se vincula, además, al fenómeno de la colonización griega y fenicia, aunque parece que el «factor» fenicio (ROMEO 2002, p. 170 y ss.), o púnico (IBIDEM. p. 173), se apunta como más determinante en la historiografía más reciente.

En el área celtibérica este tipo de defensas cuadrangulares aparecerían supuestamente en un momento más tardío no siendo, «en ningún caso», anteriores al siglo III a. C. (LORRIO 1997, p. 82). Además, y «apoyando» esta cronología baja, se ha subrayado su frecuente vinculación con paños «acodados» (MoreT 1991, p. 35 y ss.), lo cual se confirmaría en nuestro caso, aunque torres cuadrangulares y muro acodado no pertenezcan, desde el análisis estratigráfico, al mismo momento constructivo.

Por otra parte, Lorrio $(1997$, p. 83) señala la existencia de un grupo de amurallamientos que denomina «celtibéricoromanos» provistos de torres cuadrangulares y pertenecientes a un período incluso más tardío, y plenamente republicano, murallas entre las que incluye a la de Contrebia . Como es lógico, en este comentario Lorrio no tenía en cuenta las torres que ahora comentamos, sino que se refiere, fundamentalmente, a las únicas que entonces se reconocían y que en, términos actuales, cabe identificar con la que defiende el punto más alto del foso - fuera de los límites de nuestro estudio- y la que cubre el flanco oriental de la puerta meridional.

La primera de estas torres fue excavada por Taracena (1942, p.23) quien documentó la presencia de abundantes carbones entre los rellenos de su interior, hecho que le llevó a identificarla automáticamente con la mencionada en un relato de Tito Livio que narra las circunstancias bélicas de la toma

\footnotetext{
7 La vinculación con la presencia romana que Lorrio propone para estas murallas contrasta sensiblemente con lo expuesto recientemente por Hourcade (2003, p. 301): «Durant l'époque républicaine, la présence de ces ouvrages de flanquement ne semble pas systématique et l'on connaîtrait mème, pour la côte catalane et la basse vallé de l'Ebre, une série de villes, datées de la fin du IIe ou du début du Ier s. A.C., qui n'en possèderaient pas».
}

de la ciudad de Contrebia por parte de las tropas sertorianas, episodio ocurrido al parecer en el año 77 a. C. No nos parece necesario realizar ahora comentario alguno sobre la identificación de Taracena, pero sí lo es recordar que, de momento, es la única propuesta cronológica realizada para dicha torre.

Estratigráficamente, la otra torre de las comentadas por Lorrio, corresponde a la segunda fase reconstructiva de las que documentamos en la estructura de la puerta, que nada tiene que ver con la segunda fase de la muralla meridional, y a la que, recordemos, se le adosa una unidad estratigráfica en la que se documenta la presencia de cerámica de barniz negro.

En cualquier caso, tanto la torre de la zona alta de la ciudad, como la torre de la puerta, presentan rasgos tipológicos y constructivos que las diferencian netamente de las que ahora nos ocupan.

Los nuevos datos revelan también que las torres encargadas de la defensa del flanco meridional de la ciudad de Contrebia no fueron concebidas aisladamente, o lo que es lo mismo que se trata de un sistema de torres en serie del que podríamos reconocer, por el momento, restos de hasta cuatro bastiones separados entre sí por espacios irregulares pero, muy cercanos unos de otros.

Este aspecto tipológico de las torres en serie, en opinión de Tréziny (1999, p. 256), aparecería en el occidente mediterráneo a fines del siglo VI a. C. en fortificaciones fenicias, como la de la ciudad siciliana de Mozia, pero, también, en colonias foceas como Marsella o Vélia, así como en algunos yacimientos indígenas «influencés par Marseille», si bien su desarrollo y generalización podría situarse en la segunda mitad del siglo $\mathrm{V}$ y sobre todo en el IV a.C.

Para el caso hispano podría afirmarse, desde la perspectiva actual, que los paños que disponen de este sistema múltiple de flanqueo son muy poco frecuentes, ya sea en el mundo celtibérico o en el ibérico, y, cuando se documenta — caso, por ejemplo, de las murallas de Ampurias o de Ullastret (MÜLLER 1996, pp. 86 y ss.) — se trata de paños de cronología "helenística». Utilizando estos mismos argumentos Romeo (2002, p. 171) sugiere que entre los pocos rasgos que permitirían identificar una «filiación clásica» o "la presencia de influjos mediterráneos —en los recintos hispánicos - será la disposición de las torres a intervalos —más o menos - regulares». Desde luego esta es una de las condiciones que reúnen las torres que defienden la fachada sur de la murallas de Contrebia.

Otro detalle, que quizás podría resultar significativo desde es el punto de vista tipológico se refiere a la cercanía o alejamiento, por razones tácticas, de las torres. Aspecto en el que cabe comentar el hecho de que las murallas más arcaicas del mediterráneo occidental serían, precisamente, las que 
cuentan con las torres más próximas entre sí (TRÉZINY 1999, p. 256), mientras que para las murallas de la Hispania republicana, por ejemplo, «les tours ne protègent ni systématiquement, ni régulièrement, les courtines et, pour les cas les plus anciens, elles sont mème espacées d'úne centaine de mètres (Tarragona - que recordemos ha sido paralelizada en alguna ocasión con la muralla de Contrebia (ASENSIO 1995, p. 35) —, et peut-être Cordoue et Sagonte). À l'epoque tardo-républicaine, l'entraxe passe à une cinquantaine de mètres, mais, là encore, comme dans les cas des courtines, les murailles augustéennes offrent l'image d'édifices mieux défendus avec des tours espacées tres régulièrement, d'environ 20 à 30 m.» (HourCADE 2003, p. 301).

No creemos que sea posible retrasar desde los datos actuales la construcción de la segunda fase de la muralla meridional de Contrebia, a la que pertenecen las grandes torres de este sector, hasta época augustea y, en lo que se refiere al espacio que las separa, desde lo que podemos asegurar actualmente, la distancia entre los restos visibles de la torres del sector A y el del B es de sólo 14,4 mts. y la que separa este último y la correspondiente al sector $\mathrm{C}$ se elevaría únicamente hasta los $18 \mathrm{mts}$.

No son, no obstante, estos importantes aspectos los únicos criterios tipológicos que cabría reseñar historiográficamente para la morfología de las torres de este tramo meridional de las murallas de Contrebia, y parece obligado, todavía, responder a algunas de las cuestiones que tienen que ver con su relación con respecto al trazado de la propia muralla o sobre la morfología de su estructura interna.

Refiriéndonos al primero de estos criterios tipológicos, la posición sobre la muralla de las torres en este sector meridional de las defensas de Contrebia nos vuelve a situar en un escenario muy particular, puesto que como bien nos recuerda Tréziny (1999, p. 247 y ss.) «les tours internes au rempart sont rarissimes dans l'architecture militaire grecque, et ne se trouvent jamais en serie». Las «rarezas» a las que se refiere Tréziny podemos identificarlas puntualmente con las murallas de Tyndaris, sobre cuyas torres internas este autor se plantea dudas cronológicas más que razonables (ibidem., nota 30), y sobre todo en las «complejas» defensas de Hipponion, donde supuestamente sería posible reconocer, en un paño concreto de su estructura defensiva (IBIDEM. fig 5), hasta cinco torres rectangulares separadas por espacios que oscilan entre los 45 y 60 mts. y que se proyectan «à l'intériéur du rempart». Las torres cuadrangulares interiores de Hipponion pertenecerían, aún teniendo en cuenta los numerosos problemas de conservación, identificación y, también, de datación que nos recuerda Tréziny (IBIDEM. p. 247 y ss.), a la denominada fase $\mathrm{B} 1$ anterior claramente a la fase $\mathrm{D}$ «qui ne semble pas antérieure à la fin du IVe s.» (IBIDEM.p. 248).
Sí la torres de flanqueo cuya planta se desarrolla al interior de la alineación de muralla son muy escasas en las fortificaciones del Mediterráneo occidental, en la Península Ibérica podríamos decir que son prácticamente inexistentes en las murallas prerromanas y ausentes por completo en las defensas de las ciudades de la Hispania republicana.

Volviendo de nuevo a nuestra muralla de Contrebia, nos parece necesario recordar, en este aspecto, la posición estratigráfico-constructiva que atribuimos a estas torres «interiores» ya que, al pertenecer a la segunda fase constructiva, su singular desarrollo hacia el interior de la ciudad podría explicarse, sencillamente, por la preexistencia del foso.

De mayor calado tipológico nos parece la segunda característica señalada antes, es decir la estructura interna de las torres, estructura que podríamos definir como de «interior compartimentado» (HERNÁNDEZ VERA 2003, p. 71) o, manejando la denominación utilizada por Tréziny (1999, p. 261), como "tours à caissons». Son torres normalmente de gran tamaño, más de 70 metros cuadrados en el caso de las de Contrebia, y su prototipo para el Mediterráneo occidental lo proporciona de nuevo el ya mencionado amurallamiento de la colonia fenicia de Mozia en Sicilia, cuya construcción se remonta con seguridad al siglo VI a. C. (CIASCA 1986, p. 221 y ss.; 1993, pp. 21 y ss.; GARBINI 1993, pp.67 y ss.). No obstante, en opinión de Tréziny este tipo de torres, entre otros avances poliorcéticos cuyos precedentes se documentan en época arcaica, sólo serían sistemáticamente utilizados a partir de mediados del siglo IV a. C. (TréZINY 1999, p. 261).

En la Península, los ejemplos de torres compartimentadas se limitaban, hasta ahora, exclusivamente al área ibérica y entre las conocidas cabe destacar las del poblado de Alorda Park (Tarragona) datadas, en principio, en el siglo VI a. C. (SANMARTí Y SANTACANA 1991, p. 330 y ss.); la torre III de las defensas de Ullastret (Gerona) de finales del siglo IV a.C. (MoreT 2002, p. 198); la de Rochina (Castellón), con una cronología más avanzada (MORET 1996, p. 451); así como las del segundo recinto de la muralla de Malaka y las del Tossal de Manises (Alicante). En el caso de Malaka la cronología propuesta se remontaría también al siglo VI a. C y se relacionaría con la presencia fenicia en esta ciudad (LóPEZ CASTRO 2002, p. 88), mientras que para el caso alicantino se ha planteado la posibilidad de reconocer una marcada influencia constructiva púnica y, más concretamente, de época bárquida (OlCiNA 2002, p. 256), aunque en este caso se trata de torres de planta oblonga.

A todos estos modelos tipológicos cercanos, nos habíamos referido anteriormente en otro lugar (HERNÁNDEZ VERA 2003, p. 281) y, por el momento, sólo los podemos complementar refiriéndonos a una nuevo ejemplo, la gran 

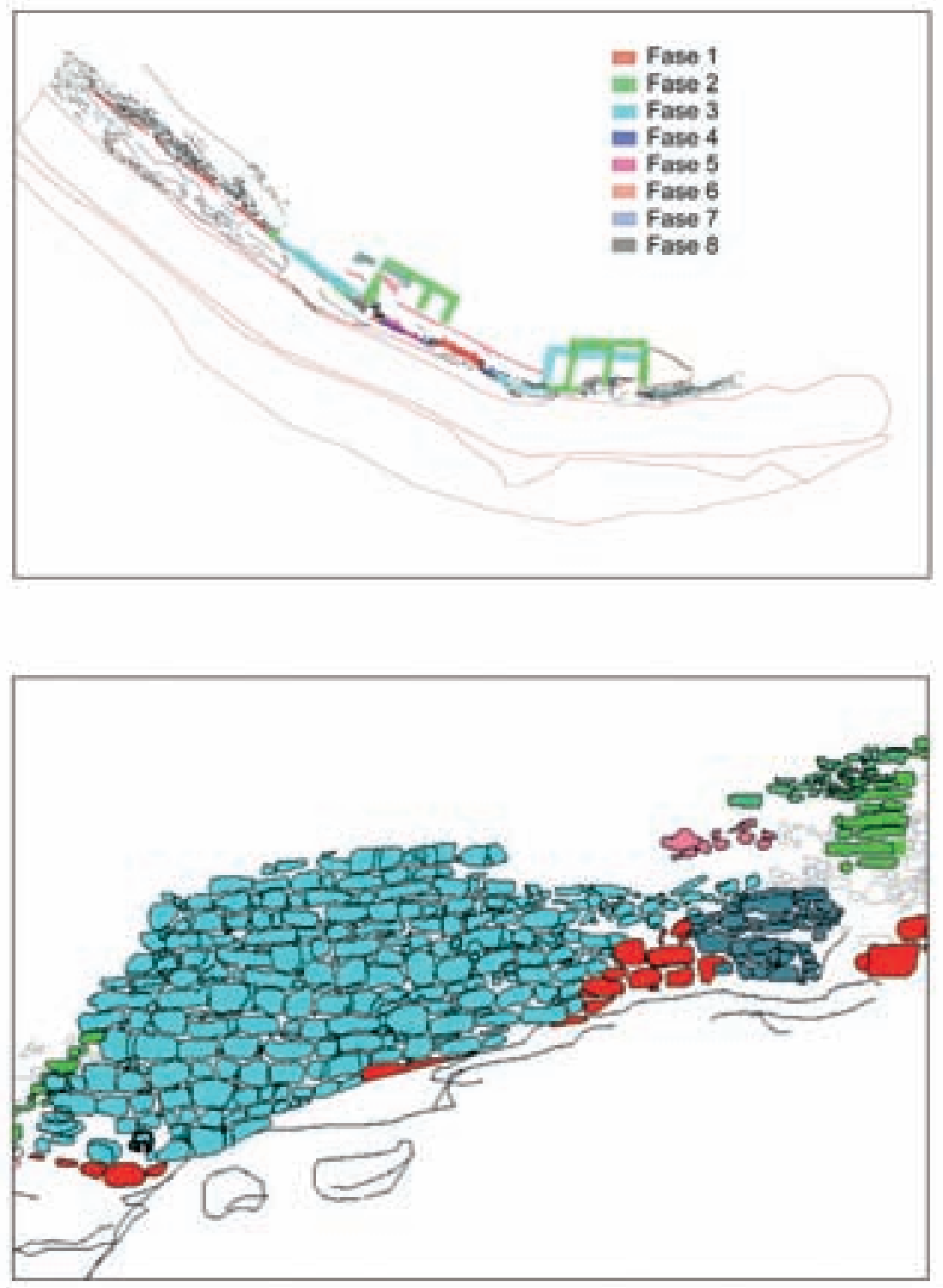

\section{Sector A}

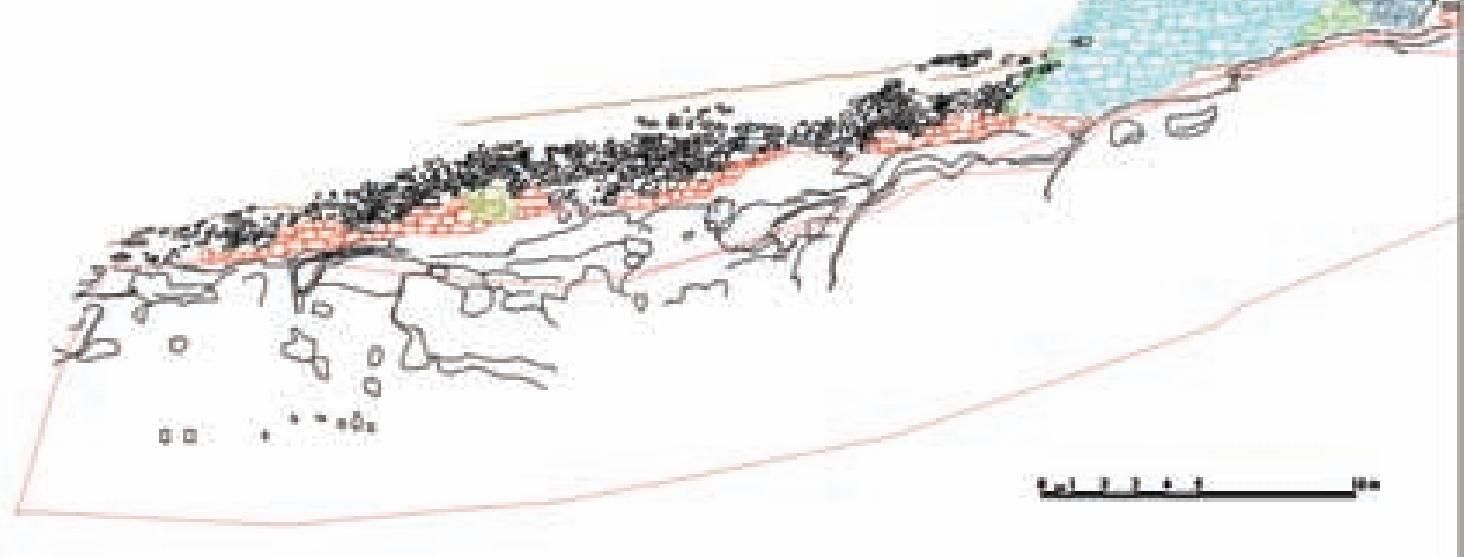



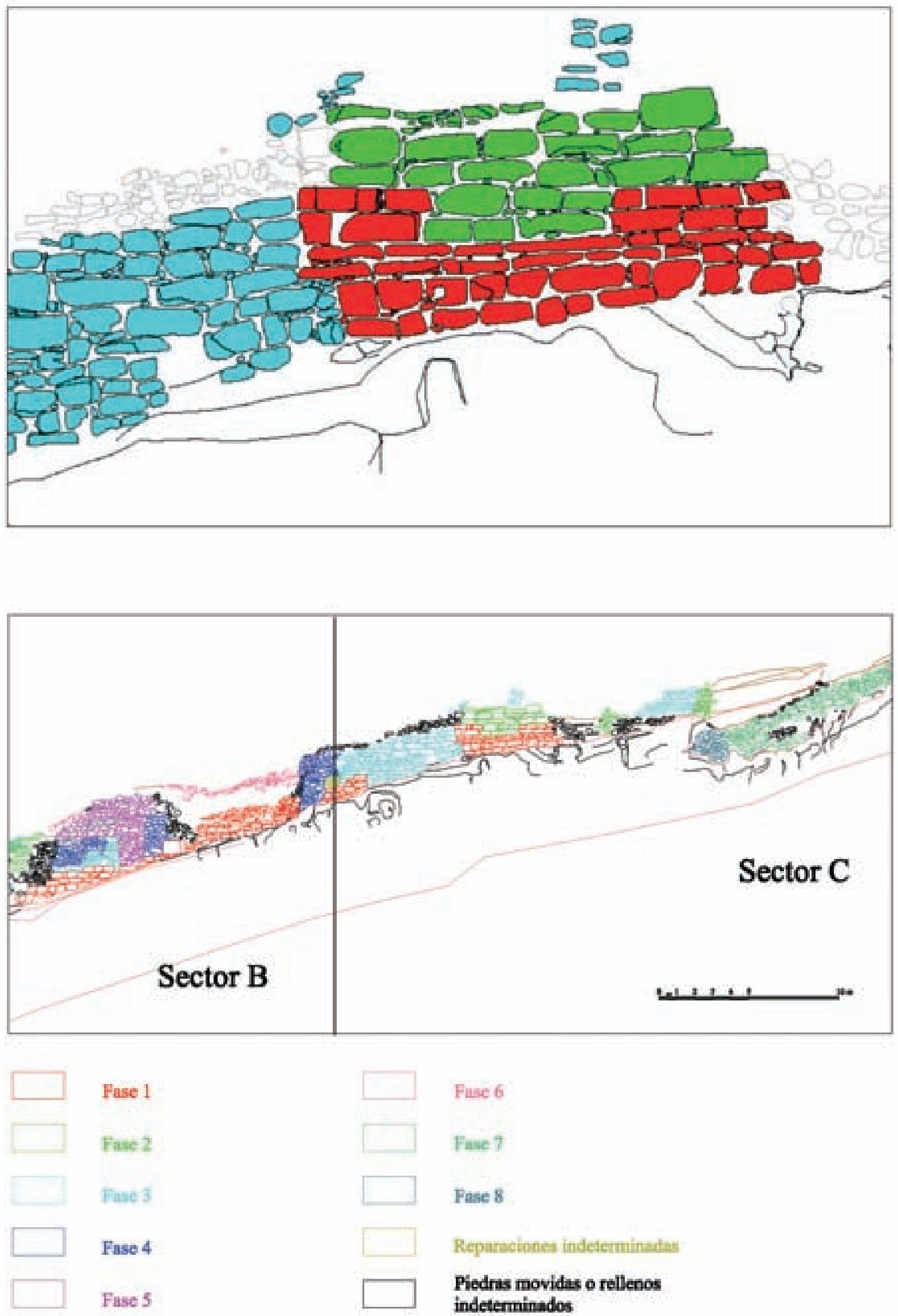

Fase 6

\section{Fase 7}

Fase 8

Reparnciones indeterminadas

Piedras movidas o rellenos indeterminados 
defensa de Torreparedones (Córdoba), edificación que aunque muestra diferencias constructivas que consideramos importantes con respecto a las torres de Inestrillas, ya que su compartimentación interna es en este caso "cruciforme», ha sido recientemente relacionada, también, con los aportes poliorcéticos púnicos, en esta ocasión, teniendo en cuenta no la tipología sino argumentos referidos al análisis metrológico de sus estructuras (MORET 2002, p. 209).

Para finalizar con este trascendente apartado dedicado a las tipología de las torres, únicamente cabría recordar que durante la excavación del bastión del sector $\mathrm{C}$ se evidenció la, más que probable, existencia de un segundo piso levantado en adobes (HeRNÁNDEZ VerA 2003, p. 70), circunstancia constructiva muy interesante pero que, en realidad, no nos aporta argumentos cronológicos destacados, habida cuenta de su manifiesta habitualidad en los encintados de las diferentes zonas y períodos históricos que tratamos, con la «excepción», ya señalada, de los amurallamientos de territorio celtibérico donde supuestamente: «Todas están realizadas en piedra a diferencia de otras zonas donde se documentan murallas de adobe y recintos mixtos...» (LORRIO 1997, p. 71). Afirmación con la que no podemos estar de acuerdo por motivos que parecen evidentes.

\section{La puerta}

El problema de la caracterización tipológica de la puerta Sur de Contrebia desde la intención señalada al comienzo de este apartado, es decir la de aportar una posible cronotipología inicial a la muralla, no resulta especialmente esclarecedora puesto que, teniendo en cuenta nuestra lectura estratigráfica, la puerta primitiva de este sector se encontraría defendida únicamente por un sencillo ensanchamiento del paramento de la muralla. Esta forma de articular la defensa de una puerta es reconocida historiográficamente en muchas murallas prerromanas de Hispania, tanto en la zona correspondiente al mundo ibérico (ROMEO 2002, p. 165) como al celtibérico (LORRIO 1997, p.84), pero en ella no parecen poder reconocerse, por el momento, indicadores cronotipológicos significativos.

En cualquier caso, teniendo en cuenta los valores métricos del mencionado ensanchamiento de la muralla y su posición, seguro que nada inocente, sobre el flanco derecho de cualquier posible asaltante, se nos plantean serias dudas sobre sí dicho ensanchamiento podría considerarse, o no, como una auténtica «torre» que cumpliría, además, con los supuestos objetivos tácticos considerados de origen mediterráneo.

Otro problema que nos preocupa en relación con la datación de las defensas más antiguas de la puerta, es el que tiene que ver con la primera torre de flanqueo de este acceso meridional de la ciudad y se refiere a la posibilidad de que pueda identificarse erróneamente con las torres de la muralla sur comentadas más arriba. En este sentido, creemos oportuno recordar, de nuevo, que las fases establecidas para los paños de la muralla y para la puerta son independientes entre sí, y que dicha torre nada tiene que ver desde el punto de vista tipológico o constructivo con las que defienden el tramo meridional de la muralla. Sobre la cronología de esta torre, no obstante, ya hemos avanzado los datos de que disponemos.

Sin entrar ahora en la discusión de cuestiones metodológicas más complejas que acompañan al problema que nos ocupa, lo que sí nos parece obligado concluir es que: «eliminada» la existencia de las supuestas «murallas de cajones", los defensores de una cronología hispano-romana para la muralla de Contrebia carecen de cualquier soporte argumental sólido y también que, a tenor de lo comentado antes, nada impide proponer para sus primeras fases constructivas una cronología más alta.

En este sentido, el conjunto de los elementos cronotipológicos comentados nos permitirían situar la construcción de sus dos primeras fases, sin problemas de justificación, en un período de tiempo comprendido entre finales del siglo IV y finales del III a. C.

\section{Bibliografía}

ADAM, J. P., L'architecture militaire grecque, París, 1982.

ADAM, J.P., Les composantes d'une fortification grecque, Les Dossiers d'Archéologie, 172, 1992, pp. 14-36.

Aguilera Aragón, I., El poblamiento celtibérico en el área del Moncayo, en: F. Burillo (coord.), Poblamiento celtibérico. III Simposio sobre los celtíberos, Zaragoza, 1995, pp. 213-233.

Arlegui, M., El yacimiento arqueológico de "Castilmontán», Somaén (Soria): El sistema defensivo, II Symposium de Arqueología Soriana (Soria 1989), T.I, 1992, pp. 495-513.

AsEnsio, J. A., Primeras manifestaciones del urbanismo romano-republicano en el valle medio del Ebro: Una nueva interpretación sobre las ciudades en llano de planta ortogonal en Aragón de finales del siglo II y comienzos del i a.E., Zephyrus XLVII, 1994, pp. 219-255.

Asensio, J. A., La ciudad en el mundo prerromano en Aragón, Caesaraugusta, 70 (número monográfico), 1995.

ASENSIO, J. A., Influencia de la poliorcética tardo-republicana en los sistemas defensivos de las ciudades indígenas del valle medio del Ebro: El caso de las murallas denominadas de cajones, Anas, 9, 1996, pp. 21-36.

Aumüller, Th., Die Stadtmauern von Hipponium. Ergebnisse der Bauforschung am Nordostflügel der griechischen Stadmauern von Vibo Valentia, M.D.A.I. (R), 101, pp. 241-278.

AZKARATE, A., Intereses cognoscitivos y praxis social en Arqueología de la Arquitectura, Arqueología de la Arquitectura, 1, Vitoria 2002, pp. 55-71.

Burillo Mozota, F., Aproximación diacrónica a las ciudades antiguas del valle medio del Ebro, Teruel, 1986.

Burillo Mozota, F., Los celtíberos: Etnias y estados, Barcelona, 1998.

Capalvo, A., Celtiberia, Zaragoza, 1996.

Casado López, P. y Hernández Vera, J. A., Materiales del Bronce Final de la cueva de los Lagos (Logroño), Caesaraugusta 47-48, Zaragoza, 1979, pp. 97-125. 
CiASCA, A., Fortificazioni di Mozia (Sicilia). Dati tecnici e proposta preliminare di periodizzazione, en La fortification dans l'histoire du monde grec, (Actes du colloque international, (Valbonne, 1982), París, 1986, pp. 221-227.

CiASCA, A., Sulle mura di Mozia, Studi sulla Sicilia Occidentale in onore di Vincenzo Tusa, Padua, 1993, pp. 27-31.

Garbini, G., La caduta di Mozia, Studi sulla Sicilia Occidentale in onore di Vincenzo Tusa, Padua, 1993, pp. 67-72.

Garlan, Y., Recherches de Poliorcétique Grecque, B.E.F.A.R., 223, París, 1974.

Hernández Vera, J. A., Las ruinas de Inestrillas. Estudio arqueológico, Logroño, 1982.

Hernández Vera, J. A., La fundación de Graccurris, Valencia y las primeras ciudades romanas de Hispania. Valencia, 2002, pp. 173-182.

Hernández Vera, J. A., Contrebia Leukade y la definición de un nuevo espacio para la Segunda Guerra Púnica, Saldvie, 3, 2003, pp. 61-82.

Hernández Vera, J. A., Ariño Gil, E., NúÑEz Marcén, J. y MartíNEZ Torrecilla, J. M., Graccurris. Conjuntos monumentales en la periferia urbana: puentes, presas y ninfeos, Graccurris 4 (número monográfico), Alfaro, 1995.

Hernández Vera, J. A., Gutiérrez González, F. J. y Martínez ToRRECILLA, J. M., Contrebia Leukade. Materiales metálicos de la última ocupación, Estrato 7, 1996, pp. 25-31.

Hernández Vera, J. A., GutiérRez GonZÁlez, F. J. y Martínez ToRRECILLA, J. M. (1997), Contrebia Leukade. El alzado de la casa V-J-6, Estrato 8, 1997, pp. 10-14.

Hernández Vera, J. A. y Martínez Torrecilla, J. M. (1994), Contrebia Leukade: Consideraciones sobre el material cerámico, Estrato 6, 1994, pp. 25-30.

HERNÁNDEZ VerA, J. A. y NuÑEZ, J., La colección de cerámica de barniz negro procedente de Gracurris (Alfaro, La Rioja), en: La ceràmica de vernis negre dels segles II $i$ I aC: Centres productors mediterranis $i$ comercialització a la Península Ibérica, Mataró, 2000, pp. 281-285.

Hernández Vera, J. A. y Sopeña Genzor, G., Acerca de una vasija celtibérica con decoración de cabezas humanas hallada en las excavaciones de Contrebia Leukade, Aguilar del río Alhama, Estrato 3, 1990, pp. 40-44.

HourCADE, D., Les murailles des villes romaines de l'Hispanie Republicaine et Augusteenne: enceintes ou fortifications du territoire urbain?, en: Defensa y territorio en Hispania de los Escipiones a Augusto; espacios urbanos, rurales, municipales y provinciales, Madrid, 2003, pp. 295-324.

López Castro, J. L., Las ciudades fenicias occidentales, en: Valencia y las primeras ciudades romanas de Hispania, Valencia, 2002, pp. 81-92.

LORRIO, A. J., Los Celtíberos, Complutum (número monográfico), 1997.

Martin, R., Manuel d'Architecture grecque I. Matériaux et techniques. París, 1965.

Moret, P., Les fortifications de l'Age du Fer dans la Meseta espagnole: origines et diffusion des techniques de construction, M.C.V., 27 (1), 1991, pp. 5-42.

MORET, P., Facteurs indigènes el exogènes dans lévolutión de l'arqchitecture defensive iberique Fortificatios. La problemàtica de l'ibèric ple:
(Segles IV-III) Simposi internacional d'arqueologia ibèrica. Manresa, 1991, pp. 265-270-271.

MORET, P., Les fortifications ibériques. De la fin de l'Age du Bronce à l'époque romaine, Collection de la Casa de Velázquez, 56, Madrid, 1996.

MORET, P., Les fortications Ibériques complexes. Questions de tracé et d'unité de mesure, en: La guerra en el mundo Ibérico y Celtibérico (ss. VI-II a. C.); Collection de la Casa de Velázquez, 78, Madrid, 2002, pp. 190-215.

Moret, P., Fortifications Ibériques tardives et défense du territoire en Hispanie Citérieure, en: Defensa y territorio en Hispania de los Escipiones a Augusto; espacios urbanos, rurales, municipales y provinciales, Madrid, 2003, pp. 159-183.

MÜLLER, H., Beobachtungen an Befestigungsanlagen in Katalonien. Elemente griechischer Befestigungstechnik in Emporion, Ullastret und Tivissa, $M D A I(M), 37,1996$, pp. 86-102.

OlcinA, M. H., Lucentum, en: Valencia y las primeras ciudades romanas de Hispania, Valencia, 2002, pp. 255-266.

RomeO, F., El impacto de Roma en los sistemas defensivos Ibéricos del Valle Medio del Ebro, en: IV. ${ }^{a}$ Jornadas nacionales de Historia Militar. El Mediterráneo: hechos de relevancia histórico-militar y sus repercusiones en España, Sevilla, 1997, pp. 115-140.

RomeO, F., Las fortificaciones Ibéricas del Valle Medio del Ebro y el problema de los influjos mediterráneos, en: P. MORET y F. QUESADA (eds.), La guerra en el mundo Ibérico y Celtibérico (ss. VI-II a. C.); Collection de la Casa de Velázquez, 78, Madrid, 2002, pp. 153-188.

Romero Carnicero, F., Los castros de la Edad del Hierro en el norte de la provincia de Soria, Valladolid, 1991.

SÄFLUND, G., Te Dating of Ancient Fortifications in South Italy an Greece, with special reference to Hipponium, Acta Inst. Romani Regni Sueciae, 4, 1935, pp. 87-119.

SANMARTí, J. y SANTACANA, J., Les fortificacions ibériques de la Catalunya central i costanera, en: Fortificacions. La problemàtica de l'iberic ple: (segles IV-III A.C.)Simposi internacional d'arqueologia ibérica, Manresa, 1991, pp. 127-144.

Sanmartí, J. y Santacana, J., El sistema defensiu del poblat ibèric d'Alorda Park (Calafell, Baix Penedès, Tarragona),en: Fortificacions. La problemàtica de l'iberic ple: (segles IV-III A.C.) Simposi internacional d'arqueologia ibèrica, Manresa, 1991, pp. 329-335.

SChulten, A., Fontes Hispaniae Anticuae III, Barcelona, 1935.

TARACENA, B., Noticias de un despoblado junto a Cervera del río Alhama, Archivo español de Arte y Arqueología, Tomo II, 1926, pp. 137-142.

TARACEnA, B., Restos romanos en La Rioja, A.E.A., 46, 1942, pp. 17-47.

Taracena, B., Los pueblos celtibéricos, en: Menéndez Pidal, R. Historia de España. 1 (3), Los pueblos prerromanos, Madrid, 1954, pp. 195-299.

Traggia, J., Aparato a la historia eclesiástica de Aragón, T. I, Madrid, 1792.

TRÉZINY, H., L'architecture militaire grecque en Occident, en: Grecs en Occident. De l'áge mycénien a la fin de l'Hélenisme, Milán, 1996, pp. 348-352.

TRÉZINY, H., Les fortifications grecques en Occident à l'époque classique (491-322 av. J.-C.), Pallas, 51 (número monográfico) en: Guerres et sociétés dans les mondes grecs à l'époque classique), 1999, pp. 241-282. 